Review

\title{
Progress in carbon monoxide oxidation over nanosized Ag catalysts
}

\author{
ZHANG Xiaodong, QU Zhenping*, YU Fangli, WANG Yi \\ Key Laboratory of Industrial Ecology and Environmental Engineering, Ministry of Education, School of Environmental Science and Technology, \\ Dalian University of Technology, Dalian 116024, Liaoning, China
}

\section{A R T I C L E I N F O}

\section{Article history:}

Receieved 24 January 2013

Accepted 27 April 2013

Published 20 July 2013

\section{Keywords:}

Supported silver catalyst

Carbon monoxide oxidation

Preparation method

Pretreatment condition

\begin{abstract}
A B S T R A C T
Nanosized Ag catalysts have attracted much attention because of their unique catalytic properties for various reactions, in particular for $\mathrm{CO}$ oxidation at low temperatures. Recently, Ag catalysts displaying high catalytic activities and reaction stabilities, and good application prospects in the elimination of CO, even at ambient temperature, have been developed. In this review, combined with our group's research, the different influencing factors such as the preparation method, support, pretreatment conditions, second component, other atmosphere, and reaction mechanisms are discussed in detail and summarized.
\end{abstract}

(C) 2013, Dalian Institute of Chemical Physics, Chinese Academy of Sciences. Published by Elsevier B.V. All rights reserved.

\section{Introduction}

CO is one of the key pollutants in many industrial and indoor environments. CO combines easily with hemoglobin in the human body, and this damages the central nervous system. At present, the catalytic oxidation of $\mathrm{CO}$ is a common way of removing $\mathrm{CO}$. The catalytic oxidation of $\mathrm{CO}$ to $\mathrm{CO}_{2}$ at low temperatures is an important process for environmental protection and has widespread applications in air purification for buildings or vehicles, closed-cycle $\mathrm{CO}_{2}$ lasers, $\mathrm{CO}$ detectors [1,2], and CO selective oxidation in reformer gas for fuel-cell applications [3-5]. In addition, the CO molecule is used as a probe molecule to study the relationship between the catalyst structure and performance. Catalytic CO removal is therefore important in basic research and practical applications.

Since the 1980s, the hopcalite catalyst and noble-metal catalysts containing $\mathrm{Au}, \mathrm{Pd}$, or Pt have been used in the catalytic oxidation of $\mathrm{CO}$ to $\mathrm{CO}_{2}$. However, the hopcalite catalyst has poor water resistance, and noble-metal catalysts are expensive [6]. In recent years, many reviews of $\mathrm{Au}$ catalysts [2,7-14] and some non-noble-metal catalysts [15-20] for CO oxidation have been published. Ag catalysts, which are relatively cheap, show excellent low-temperature activities for many catalytic oxidation reactions such as $\mathrm{NO}_{x}$ abatement, ethylene epoxidation, and methane oxidation [21-23]. As the $d$-orbital of the Ag atom is completely filled (first ionization energy $=731 \mathrm{~kJ} / \mathrm{mol}(7.58$ $\mathrm{eV}$, electronegativity = 1.9), it is difficult for Ag to lose electrons. The interactions between Ag and reactant molecules are therefore very weak. Studies have indicated that new oxygen species are formed on restructured $\mathrm{Ag}(111)$ [24]; the activities of these species are much higher in some reactions (e.g., CO oxidation) than those of surface-adsorbed oxygen species. However, few reviews of Ag catalysts for $\mathrm{CO}$ oxidation have been published.

In this review, based on our studies of $\mathrm{Ag}$ catalysts for low-temperature CO oxidation, different factors such as the

\footnotetext{
*Corresponding author. Tel: +86-15542663636; Fax: +86-411-84708083; E-mail: quzhenping@dlut.edu.cn

This work was supported by the Program for New Century Excellent Talents in University (NCET-09-0256), the National High Technology Research and Development Program of China (863 Program, 2009AA062604), and the Program for Liaoning Representative Office of China Environmental Protection Foundation (CEPF2010-123-1-10).

DOI: 10.1016/S1872-2067(12)60610-X | http://www.sciencedirect.com/science/journal/18722067 | Chin. J. Catal., Vol. 34, No. 7, July 2013
} 
preparation method, support, pretreatment conditions, second component, other atmosphere, and reaction mechanisms are discussed in detail and summarized. This review will further promote research and development of $\mathrm{Ag}$ catalysts for low-temperature $\mathrm{CO}$ oxidation.

\section{Effect of preparation method}

The melting point of $\mathrm{Ag}\left(960^{\circ} \mathrm{C}\right)$ is lower than those of $\mathrm{Au}$ $\left(1063^{\circ} \mathrm{C}\right), \operatorname{Pd}\left(1550^{\circ} \mathrm{C}\right)$, and $\mathrm{Pt}\left(1769^{\circ} \mathrm{C}\right)$, and $\mathrm{Ag}$ nanoparticles tend to sinter at high temperatures. The design of the preparation method is therefore very important. It is known that the dispersion and particle size of $\mathrm{Ag}$ affect the interactions between Ag and the carrier, resulting in different catalytic activities for CO oxidation [25]. At present, supported Ag catalysts are usually prepared by methods such as impregnation [26-28], cation-exchange [29], mixing [30,31], combustion [32], simple solid-state reactions [33], supercritical fluid deposition [34,35], post-synthesis grafting [36-38], direct synthesis [25,39-43], coprecipitation [44-49], and deposition-precipitation [50,51].

$\mathrm{AgAu} / \mathrm{SiO}_{2}-\mathrm{Al}_{2} \mathrm{O}_{3}$ catalysts have been prepared using a modified incipient wetness impregnation method (using sinensis as a reducing agent) [28]. The one-step bioreduction procedure has two advantages compared with conventional deposition-precipitation methods: (1) the method is simple and the metallic particles can be obtained in one step, and (2) the synthesized nanoparticles are small and homogeneously distributed. Xia et al. [29] reported that Ag/OMS-2 catalysts prepared using a cation-exchange method exhibited very stable performance over long times on stream (1800 min). In our previous study [30], Ag nanoparticles and $\mathrm{SiO}_{2}$ powder were mechanically mixed and ground to form a uniform mixture. The supported Ag catalysts prepared with $\mathrm{O}_{2}$ at $500-700{ }^{\circ} \mathrm{C}$ displayed high thermal stability, and the Ag particles were much smaller than unsupported Ag nanoparticles. Bera et al. [32] reported a combustion mixture for the preparation of $\mathrm{Ag} / \mathrm{CeO}_{2}$. The combustion technique produces ionically dispersed $\mathrm{Ag}$ on a nanocrystalline $\mathrm{CeO}_{2}$ surface. The higher catalytic activity of combustion-synthesized $\mathrm{Ag} / \mathrm{CeO}_{2}$ has been attributed to the ionically dispersed $\mathrm{Ag}^{+}$on the $\mathrm{CeO}_{2}$ surface. Chen et al. [33] reported the synthesis of Ag-OMS-2 catalyst, and it was found that extensive substitution of $\mathrm{K}^{+} \mathrm{by}_{\mathrm{Ag}}$ induced the formation of a large number of active sites. The tunnel structure and nanorod morphology favored effective $\mathrm{CO}$ adsorption and the activation of oxygen molecules, giving high activity for $\mathrm{CO}$ oxidation at low temperatures $\left(T_{100}=90^{\circ} \mathrm{C}\right)$.

The Ag catalysts prepared by the methods mentioned above have good catalytic activities, but the subsequent activation and reaction processes easily induce aggregation of Ag particles, resulting in decreased catalytic activity. Recently, many researchers have found that confinement by ordered mesopores of mesoporous silica materials plays a crucial role in improving the thermal stabilities of Ag nanoparticles. Yin et al. [34] reported the preparation of $\mathrm{Ag} / \mathrm{SBA}-15$ nanocomposites using the supercritical fluid deposition method. This method mainly takes advantage of the fact that the surface tension of a super-

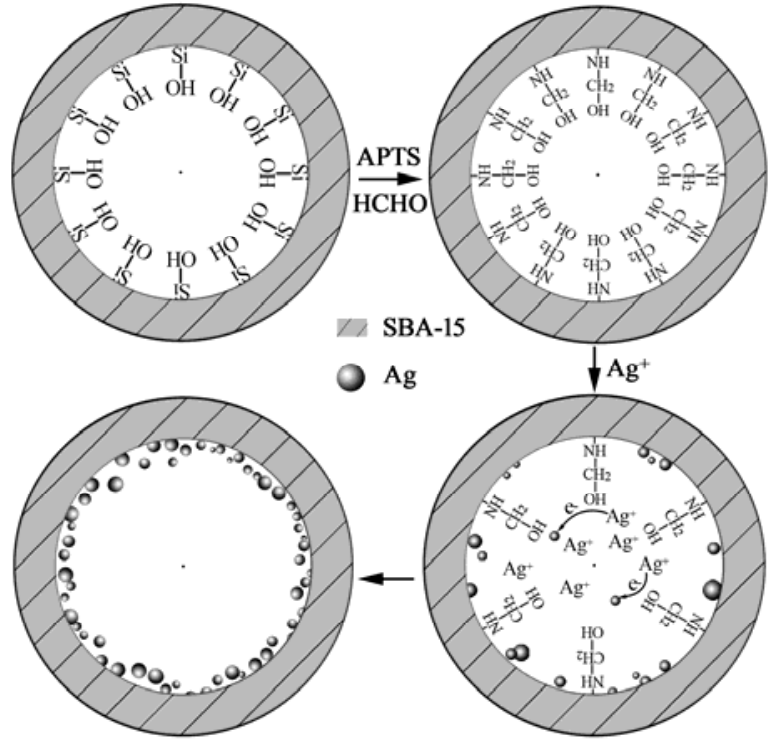

Fig. 1. Formation mechanism of Ag/SBA-15 catalyst using post-grafting method.

critical fluid is zero, and larger numbers of Ag precursor species are likely to spread to the slit and form small metal Ag particles. The addition of a cosolvent significantly improved the solubility of $\mathrm{AgNO}_{3}$ in supercritical $\mathrm{CO}_{2}$ and resulted in the formation of Ag nanowires. These nanowires did not improve the catalytic activity and only gave $100 \%$ conversion of CO at 300 ${ }^{\circ} \mathrm{C}$. Tu et al. [36] reported the confinement of Ag nanoparticles in SBA-15 channels using the post-grafting method (Fig. 1). Importantly, the Ag/SBA-15 catalyst was found to exhibit high activity for $\mathrm{CO}$ oxidation. Yen et al. [37] reported the preparation of Au-Ag bimetallic nanoparticles supported on mesoporous silica by the above method; the nanoparticles were very active for low-temperature $\mathrm{CO}$ oxidation $\left(T_{100}=30^{\circ} \mathrm{C}\right)$. Recently, a post-grafting method has been developed for the synthesis of very small and sintering-resistant bimetallic $\mathrm{Au}-\mathrm{Ag}$ particles on commercial silica [38]; the particles were highly catalytically active for $\mathrm{CO}$ oxidation $\left(T_{100}=0^{\circ} \mathrm{C}\right)$. However, the post-grafting method is relatively complicated, and in some cases the process has to be carried out under conditions that exclude water and oxygen.

Direct synthesis procedures are relatively simple and have attracted much attention recently. It is difficult to graft Ag particles onto SBA-15 in strongly acidic media. To solve this problem we prepared Ag/SBA-15 using a method, in which the $\mathrm{pH}$ was adjusted $[39,40]$. Compared with the catalysts obtained in previous studies [41-43], highly ordered Ag/SBA-15 with a high Ag content (7.9 wt\%) and highly dispersed Ag nanoparticles was successfully synthesized and showed good catalytic activity (Fig. 2). In addition, Liu et al. [25] recently reported a modified one-pot approach to the preparation of Ag nanoparticles on silica; the prepared Ag catalysts displayed good catalytic activity, and $100 \%$ conversion of $\mathrm{CO}$ was achieved at $30^{\circ} \mathrm{C}$ (Fig. 3).

\section{Effect of pretreatment}




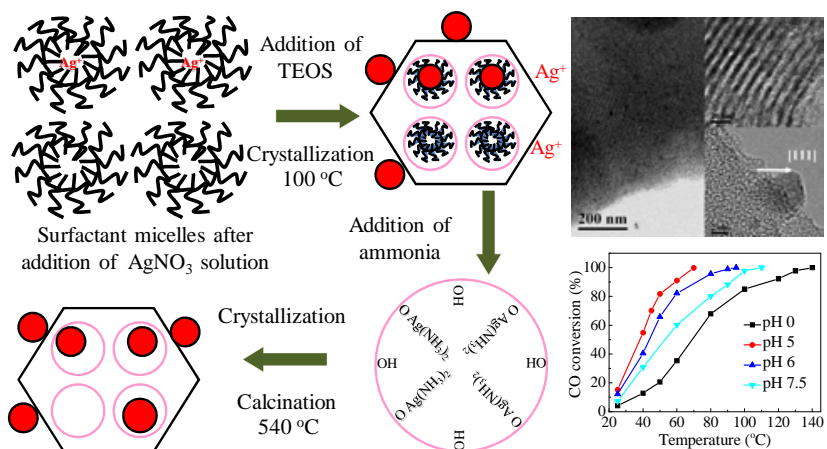

Fig. 2. Formation mechanism of Ag/SBA-15 nanocomposites using the $\mathrm{pH}$-adjusting method (left); transmission electron microscopy images (upper right) and CO conversions (lower right) of Ag/SBA-15 nanocomposites $[39,40]$.

Calcination is a necessary process for the preparation of supported Ag catalysts, and the process can induce interactions between the metal and the support. Our previous studies indicated that if the $\mathrm{Ag}$ nanoparticles and $\mathrm{SiO}_{2}$ were only mechanically mixed and ground to form a uniform mixture, the catalyst showed low activity for $\mathrm{CO}$ oxidation. However, it became catalytically active after treatment with oxygen at a certain temperature [30]. Recently, it was reported [31] that the $\mathrm{Ag} / \mathrm{Al}_{2} \mathrm{O}_{3}$ catalyst prepared from a physical mixture of $\mathrm{Ag}$ and $\mathrm{Al}_{2} \mathrm{O}_{3}$ powders showed high catalytic activity and durability for $\mathrm{CO}$ oxidation after calcination at high temperature $\left(1000^{\circ} \mathrm{C}\right)$. Aging- and catalysis-induced restructuring are therefore important concepts in designing active and durable catalysts.

Recently, we reported that a Ag/SBA-15 catalyst with low loading (1.42 wt\%) showed excellently activity in CO oxidation at $20^{\circ} \mathrm{C}$ after oxygen pretreatment at $900{ }^{\circ} \mathrm{C}\left(\mathrm{T}_{98}=20^{\circ} \mathrm{C}\right)$ [52]. An evaporation-deposition-diffusion mechanism for the Ag/SBA-15 catalyst was proposed (Fig. 4). The oxygen adsorbate caused a decrease in the surface free-energy at $900{ }^{\circ} \mathrm{C}$ and induced redeposition of the evaporated $\mathrm{Ag}$ atoms on the support, and Ag diffused into the channels of SBA-15, forming more highly dispersed small Ag particles inside the channels. We have also found that different pretreatment atmospheres

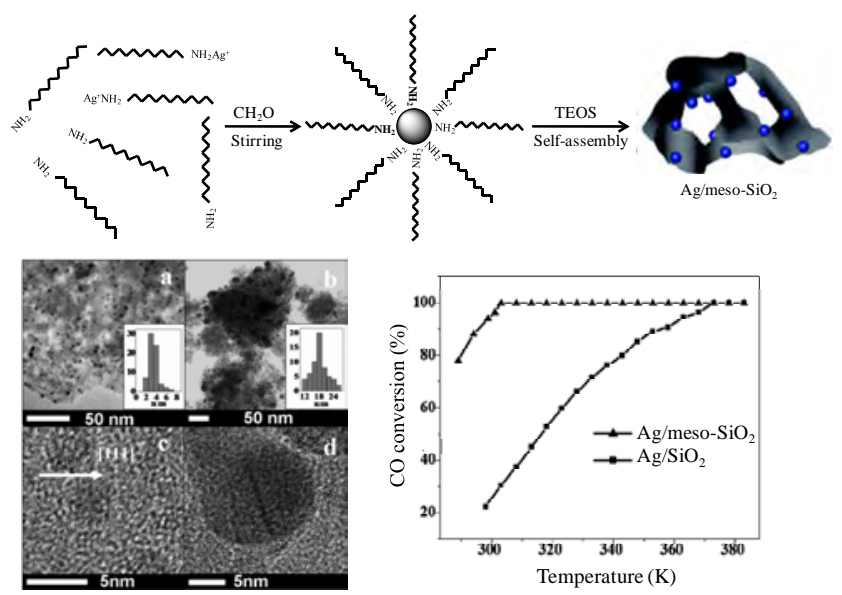

Fig. 3. Formation mechanism of $\mathrm{Ag} /$ mesostructured silica catalyst (top); transmission electron microscopy images (bottom left) and CO conversions (bottom right) of supported Ag catalysts [25].

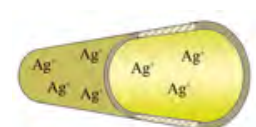

$\mathrm{AgNO}_{3} / \mathrm{SBA}-15$

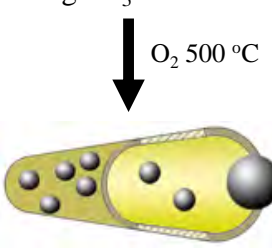

Ag/SBA-O500

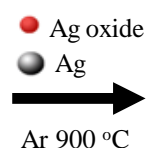

$\operatorname{Ar} 900^{\circ} \mathrm{C}$
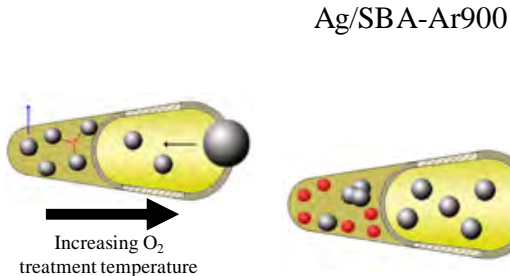

treatment temperature

$\longrightarrow$ Aggregation

$\longrightarrow$ Diffusion

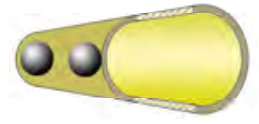

Ag/SBA-Ar900

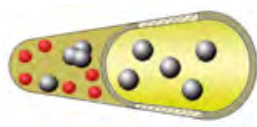

Ag/SBA-O900

Fig. 4. Schematic diagram of structural changes in Ag/SBA-15 pretreated with different atmospheres $\left(\mathrm{O}_{2}\right.$ and $\left.\mathrm{Ar}\right)$ at 500 and $900{ }^{\circ} \mathrm{C}$ [52].

$\left(\mathrm{Ar}, \mathrm{O}_{2}\right)$ and $\mathrm{Ag}$ loadings resulted in large differences in the structures of Ag catalysts and their catalytic activities [53] (Fig. 5). Ar pretreatment was favorable for the formation of small $\mathrm{Ag}$ particles in a Ag/SBA-15 catalyst with a low Ag loading (2 wt $\%$ ). $\mathrm{O}_{2}$ pretreatment was conducive to the formation of subsurface oxygen species on larger Ag particles in a Ag/SBA-15 catalyst with high Ag loading (8 wt\%). The small metal Ag particles were the key factor in the higher catalytic activity of the Ag/SBA-15 catalyst with a low Ag loading, whereas the large number of subsurface oxygen species played an important role in the higher catalytic activity of Ag/SBA-15 catalyst with a high Ag loading.

Irradiation with $\gamma$-rays was successfully used to reduce $\mathrm{Ag}^{+}$ anchored on $\mathrm{SiO}_{2}$ to $\mathrm{Ag}$ nanoparticles at room temperature [54]; poor low-temperature activity and high activity at high temperature for CO oxidation were found. However, the $\mathrm{Ag} / \mathrm{SiO}_{2}$ catalyst prepared by calcination showed the opposite activity trend. Different pretreatments induce the formation of different Ag species, resulting in different activities for $\mathrm{CO}$ oxidation. In addition, it has been found that Ag catalysts supported on different supports need different pretreatment conditions for high activity. Our previous studies [25-27,42,55,56] showed that $\mathrm{H}_{2}$ treatment was favorable for improving the catalytic activity of $\mathrm{SiO}_{2}$-supported $\mathrm{Ag}$ catalysts. It was proposed that the high-temperature oxygen treatment induced faceting of the Ag surface and facilitated the formation of sub-

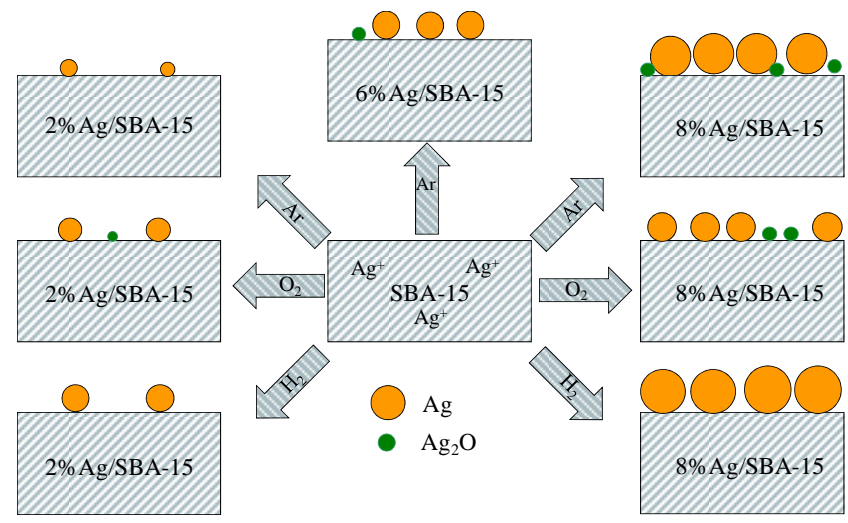

Fig. 5. Schematic diagram of $\mathrm{Ag} / \mathrm{SBA}-15$ catalysts with various $\mathrm{Ag}$ loadings pretreated under different atmospheres [53]. 


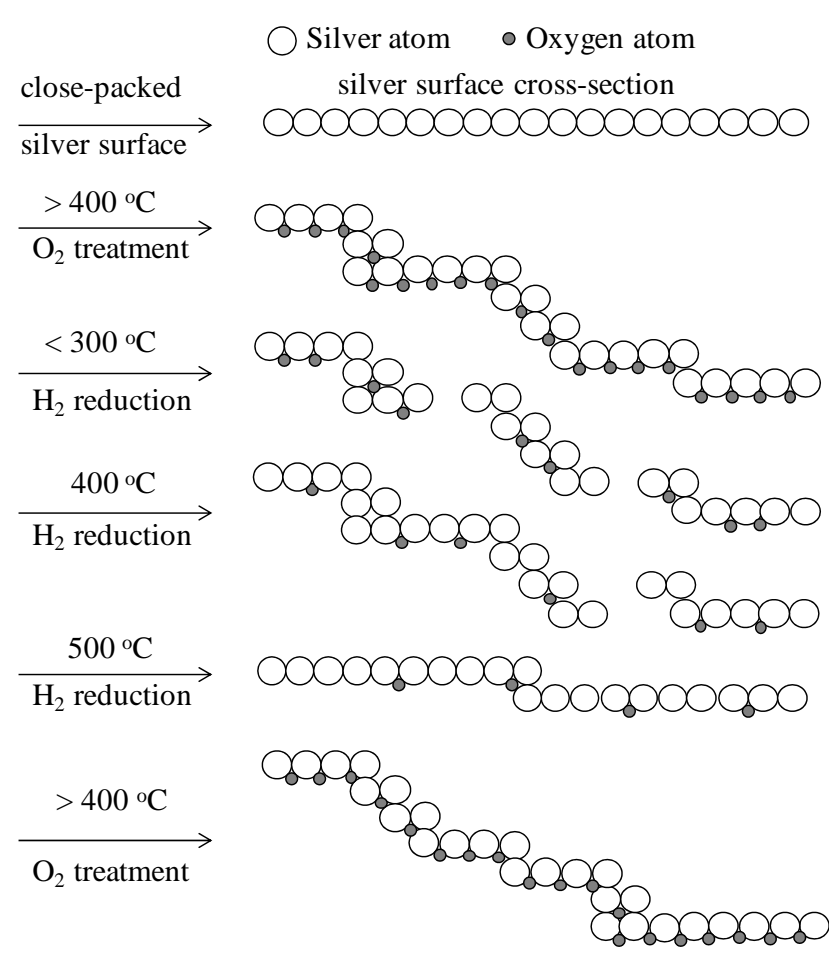

Fig. 6. Surface restructuring, subsurface oxygen formation, and redispersion model of Ag crystallites under oxidation/reduction cyclic treatment [57].

surface oxygen species and migration between the surface and the bulk of oxygen species on the Ag catalysts. When the Ag catalyst was further treated with $\mathrm{H}_{2}$ at low temperature, the redispersion of $\mathrm{Ag}$ particles resulted in larger numbers of small Ag particles, resulting in increased catalytic activity [57] (Fig. 6).

For some supports such as Ce oxide [32] and Mn oxide [58], many researchers have found that calcination improved the catalytic activity. Reduction with $\mathrm{H}_{2}$ following calcination reduced $\mathrm{Ag}_{2} \mathrm{O}$ species and also affected the structure of the carrier, which decreased the activity. Gac [58] investigated the influence of the pretreatment on the $\mathrm{CO}$ catalytic activity of $\mathrm{Ag} / \mathrm{MnO}_{x}$ catalysts and found that a large amount of active oxygen species (Mn-0) were formed on the surface of the $\mathrm{Ag} / \mathrm{MnO}_{x}$ catalyst after calcination. However, reduction with $\mathrm{H}_{2}$ after calcination slightly decreased the activities at low temperatures of the catalysts because the $\mathrm{MnO}_{x}$ structure was destroyed. Interestingly, the formation of new active sites for $\mathrm{CO}$ oxidation on $\mathrm{Ag} / \mathrm{MnO}_{x}$ catalysts after $\mathrm{H}_{2}$ reduction increased the activity at high temperatures. For all two-component catalysts containing $\mathrm{Ag}$, reduction with $\mathrm{H}_{2}$ was found to be necessary to obtain high activities for CO oxidation [37,38] (Fig. 7). Such reduction treatments reduce $\mathrm{Ag}_{2} \mathrm{O}$ and restructure the particles, which resulted in enhancement of the CO catalytic activity.

\section{Effect of support}

It is known that the catalytic activities of supported Ag catalysts are higher than those of unsupported Ag catalysts. The

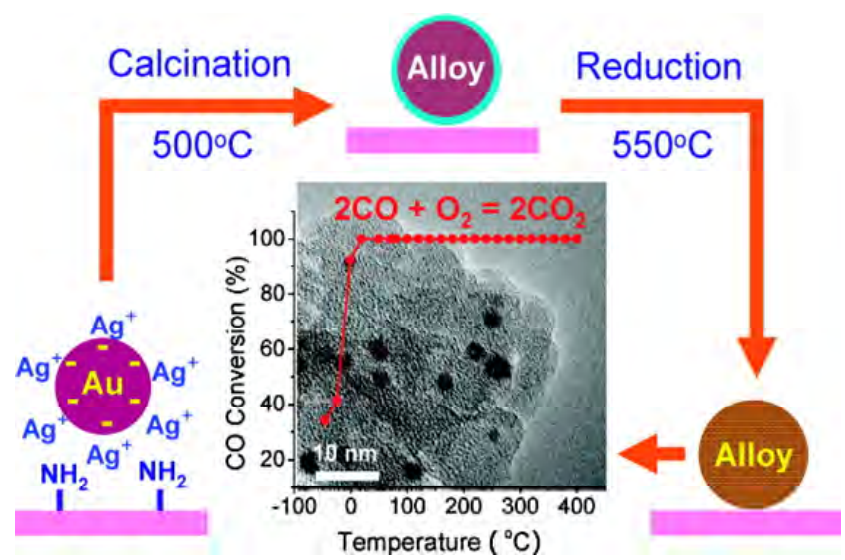

Fig. 7. Schematic diagram of structural changes and $\mathrm{CO}$ oxidation activity of $\mathrm{Au}-\mathrm{Ag} / \mathrm{SiO}_{2}$ under calcination and reduction conditions, and transmission electron microscopy image [38].

support can disperse the metal particles and induce interactions between Ag and the support [25]. At present, supports for Ag catalysts are divided into two main categories: (1) inert supports such as silica materials [25-27,42,52,53,55,56,59] and $\mathrm{Al}_{2} \mathrm{O}_{3}$ [60]; and (2) active supports such as $\mathrm{CeO}_{2}$ [32], $\mathrm{FeO}_{x}$ [45-47], $\mathrm{CoO}_{x}$ [48], $\mathrm{TiO}_{2}$ [61-64], and $\mathrm{MnO}_{x}$ [29,58,65-69]. The CO oxidation activities of Ag catalysts supported on different supports are listed in Table 1.

Silica-based Ag catalysts have been widely introduced in the pretreatment and preparation of catalysts, and it was found that silica-based Ag catalysts showed excellent activities for $\mathrm{CO}$ oxidation at room temperature [25,55], unlike silica-based $\mathrm{Au}$ catalysts. In the following part, we will discuss Ag catalysts on supports other than silica and the different active Ag species on different supports for $\mathrm{CO}$ oxidation.

The oxygen species and catalytic activities for $\mathrm{CO}$ oxidation over $\mathrm{Ag} / \mathrm{Al}_{2} \mathrm{O}_{3}, \mathrm{Ag} / \mathrm{CeO}_{2}$, and $\mathrm{Ag} / \mathrm{TiO}_{2}$ catalysts have been investigated using X-ray diffraction (XRD), temperature-programmed desorption, and temperature-programmed reduction [70,71]. The highest catalytic activity for $\mathrm{CO}$ oxidation was found on the $\mathrm{Ag} / \mathrm{Al}_{2} \mathrm{O}_{3}$ catalyst, and the catalytic activity for $\mathrm{CO}$ oxidation was strongly related to the reduction activity of the catalyst. Comsup et al. [62] found that stronger $\mathrm{Ag}-\mathrm{TiO}_{2}$ interactions improved the catalytic activity for $\mathrm{CO}$ oxidation. Doping of $\mathrm{P}$ and $\mathrm{Si}$ into $\mathrm{TiO}_{2}$ resulted in different activities $[63,64]$. The incorporation of $\mathrm{P}$ into the $\mathrm{TiO}_{2}$ lattice in the form of Ti-0-P resulted in an increase in both surface area and metal dispersion, and the adsorption ability for oxygen depended on the P precursor. The formation of Ti-O-Si inhibited the agglomeration of $\mathrm{TiO}_{2}$ crystallites, promoted the formation of active oxygen species, and increased the mobility of lattice oxygens and the catalytic activity. Hu et al. [72-74] found that CO was reversibly adsorbed on the surface of the catalyst and reacted with lattice oxygens to form $\mathrm{CO}_{2}$. The XRD results showed that the catalysts had the typical cryptomelane structure with a one-dimensional channel. Doping with Ag resulted in a higher specific surface area and narrower pore size distribution in OMS-2. The synergistic effect of ion-exchanged Ag ions and substituted Co atoms of a mordenite zeolite enhanced the CO oxidation activity [75]. 
Table 1

CO oxidation activities of Ag catalysts on different supports.

\begin{tabular}{|c|c|c|c|c|c|}
\hline Catalyst & $\mathrm{Ag}(\mathrm{wt} \%)$ & Preparation method & Treatment condition & $T_{100}(\mathrm{CO})^{\mathrm{a}}\left({ }^{\circ} \mathrm{C}\right)$ & Ref. \\
\hline Ag/Silica & 4 & One-pot synthesis method & $\mathrm{O}_{2}-\mathrm{H}_{2}$ & 30 & [25] \\
\hline $\mathrm{Ag} / \mathrm{SiO}_{2}$ & 8 & Impregnation method & $\mathrm{O}_{2}-\mathrm{H}_{2}$ & 50 & [27] \\
\hline $\mathrm{Ag} / \mathrm{SBA}-15$ & 6.86 & In-situ reduction method & $\mathrm{O}_{2}$ & 120 & [42] \\
\hline Ag/SBA-15 & 1.42 & Impregnation method & $\mathrm{O}_{2}-\mathrm{H}_{2}$ & 22 & [52] \\
\hline $\mathrm{Ag} /$ fumed silica & 4 & Impregnation method & $\mathrm{O}_{2}-\mathrm{H}_{2}$ & 30 & [55] \\
\hline $\mathrm{Ag} /$ Silica & 0.99 & One-pot synthesis method & $\mathrm{O}_{2}$ & 170 & [59] \\
\hline $\mathrm{Ag} / \mathrm{Al}_{2} \mathrm{O}_{3}$ & 29 & Impregnation method & $\mathrm{O}_{2}$ & 80 & [60] \\
\hline $\mathrm{Ag} / \mathrm{CeO}_{2}$ & 1 & Combustion method & $\mathrm{O}_{2}$ & 260 & [32] \\
\hline $\mathrm{AgFeO}_{2}$ & $\mathrm{Ag}: \mathrm{Fe}=1: 1(\mathrm{~mol} / \mathrm{mol})$ & Coprecipitation method & $\mathrm{O}_{2}$ & 130 & [45] \\
\hline Silver cobalt composite oxide & Ag:Co $=1: 1(\mathrm{~mol} / \mathrm{mol})$ & Cocipitation method & $\mathrm{O}_{2}$ & 50 & [48] \\
\hline $\mathrm{Ag} / \mathrm{TiO}_{2}$ & 10 & Solvothermal method & $\mathrm{O}_{2}$ & 150 & [63] \\
\hline Ag-OMS & 8.7 & Cation exchange method & $\mathrm{O}_{2}$ & $>100$ & [29] \\
\hline $\mathrm{Ag} / \mathrm{MnO}_{2}$ & 15 & Hydrothermal method & $\mathrm{O}_{2}$ & $>130$ & [68] \\
\hline
\end{tabular}

a Temperature for $100 \%$ conversion of CO.

The nature of the support also affects the reaction mechanism of $\mathrm{CO}$ oxidation on Ag catalysts. For inert supports, the adsorption and dissociation processes of $\mathrm{CO}$ and $\mathrm{O}_{2}$ molecules occur on the Ag surface or at the interface between Ag and the inert support. The catalytic activities of Ag catalysts are therefore largely dependent on the particle size $[57,76]$. However, because of the low Tammann temperature of $\mathrm{Ag}\left(344^{\circ} \mathrm{C}\right), \mathrm{Ag}$ catalysts have not been found to have size dependence, unlike $\mathrm{Au}$ catalysts. Our previous study indicated that Ag particles of size ca. 3-5 nm showed relatively high activity for $\mathrm{CO}$ oxidation, and $\mathrm{Ag}^{0}$ species were proposed as the active species [27]. It is known that interactions between $\mathrm{Ag}$ and hydroxyl groups on a silica surface are conducive to the formation of highly dispersed Ag particles. We therefore tried to prepare Ag catalysts with particles of different sizes by calcining silica at different temperatures and tested their CO oxidation; it was found that highly dispersed metal Ag particles showed high activity for CO oxidation at low temperatures [77]. For active supports, the lattice oxygens of the support and electron transfer between Ag-oxygen and transition metals play an important role in the catalytic activity [29]. However, the active Ag species for CO oxidation are still not clear. Luo et al. [78] thought that $\mathrm{Ag}_{2} \mathrm{O}$ was the active species for low-temperature $\mathrm{CO}$ oxidation.

As alternatives to oxide supports, some researchers have recently tried to use graphite [79] and carbon [51,80] as the support. Lim et al. [79] found that CO oxidation activity on $\mathrm{Ag} /$ graphite was very sensitive to the particle size. For Ag nanoparticles larger than $3 \mathrm{~nm}$, two different oxygen species were identified, one of which readily reacted with $\mathrm{CO}$ to form $\mathrm{CO}_{2}$ at room temperature; the activity increased with decreasing particle size. For smaller Ag nanoparticles $(<3 \mathrm{~nm})$, the formed oxygen species only reacted with oxygen atoms in the gas phase and were inert towards CO oxidation. Dai et al. [51] found that highly dispersed Ag nanoparticles were easily attached to modified carbon nanotube supports by anchoring them to oxygen-containing functional groups, and these nanoparticles exhibited higher activities for $\mathrm{CO}$ oxidation at low reaction temperatures. From the above results, we can deduce that the support plays an important role in the formation of active oxygen species and the particle size, and thus the catalytic activity.

\section{Effect of second component}

Because of their good $\mathrm{O}_{2}$ adsorption capabilities, Ag catalysts have been widely used in $\mathrm{CO}$ oxidation reactions. At present, research on Ag catalysts is mainly focused on investigation of structures and activities. However, one-component Ag catalysts have inevitable shortcomings such as high loadings and poor catalytic activities at low temperatures. Based on the current research status, some researchers have expanded the investigation of single active $\mathrm{Ag}$ species and have modified Ag catalysts with other components: (1) additives and (2) bimetallic catalysts (Au-Ag, Ag-Pd, etc.).

\subsection{Additives}

In an $\mathrm{Ag}$ catalyst, interactions between additives and $\mathrm{Ag}$ species can change the electronic structure and surface properties of the catalyst, increase the stability of Ag nanoparticles, and promote Ag dispersion, thus increasing the catalytic activity for $\mathrm{CO}$ oxidation.

Luo et al. [60,81-83] reported the catalytic activities for $\mathrm{CO}$ oxidation on $\mathrm{Ag}-\mathrm{Mn} / \gamma-\mathrm{Al}_{2} \mathrm{O}_{3}, \mathrm{Ag}-\mathrm{Co} / \gamma-\mathrm{Al}_{2} \mathrm{O}_{3}$, and $\mathrm{Ag}-\mathrm{Ce} / \gamma-\mathrm{Al}_{2} \mathrm{O}_{3}$ catalysts, and the addition of $\mathrm{MnO}_{x}, \mathrm{CoO}_{x}$, and $\mathrm{CeO}_{2}$ increased the amount of adsorbed oxygen and the capacity for surface oxygen renewal of the catalysts, consequently improving the activity. In addition, it was found that $\mathrm{CeO}_{2}$ favored the dispersion of $\mathrm{Ag}$ particles on the surface of $\mathrm{Al}_{2} \mathrm{O}_{3}$ [81]. With increasing amounts of $\mathrm{CeO}_{2}$, the $\mathrm{Ag}_{2} \mathrm{O}$ amount increased. However, the relationship between structure and activity was not discussed in this paper. Recently, we found that a small amount of $\mathrm{CeO}_{2}$ promoted dispersion of metal $\mathrm{Ag}$ particles and increased the stability of Ag nanoparticles during high-temperature $\mathrm{H}_{2}$ pretreatment, consequently improving the activity [26].

\subsection{Ag-based bimetallic catalysts}

Oxygen molecules are more easily adsorbed and activated by Ag than they are by $\mathrm{Au}$ and $\mathrm{Pd}$. Many researchers have therefore tried to prepare Ag bimetallic catalysts to improve the activation of molecular oxygen and accelerate the catalytic 
oxidation of CO.

Although supported Au catalysts have good catalytic activity for $\mathrm{CO}$ oxidation and $100 \%$ conversion of $\mathrm{CO}$ has been achieved at $0{ }^{\circ} \mathrm{C}[2]$, these $\mathrm{Au}$ catalysts have poor thermal stability and are easily deactivated in the reaction process. In order to solve these problems, Ag was used to change the electronic structure of the active metal and to activate oxygen molecules, consequently improving the reaction activity and stability of the catalyst [37,38,84-94]. Mou's group [37,38,84-87] reported that oxygen molecules activated by $\mathrm{Ag}$ can easily react with $\mathrm{CO}$ molecules activated by $\mathrm{Au}$ to form $\mathrm{CO}_{2}$, improving the catalytic activity and reaction stability. Wang et al. [88] found that oxygen species activated by Ag can be easily stored on nanoporous $\mathrm{Au}$ catalysts at room temperature. CO oxidation on an Au-enriched Ag(110) surface led to an exponential depletion of oxygen with time, shown by an in-situ time-lapsed scanning tunneling microscopy (STM) image series and density functional theory (DFT) [90]. Investigation of the kinetic mechanism of $\mathrm{CO}$ oxidation with $\mathrm{O}_{2}$ on $\mathrm{Au}-\mathrm{Ag}$ alloy indicated that $\left(\mathrm{CO}_{3}\right)^{*}$, which was formed on the Au-Ag interface as a result of co-adsorption of $\mathrm{CO}$ and $\mathrm{O}_{2}$, was decomposed to $\mathrm{CO}_{2}$, and the process was enhanced by the interactions [91]. Pd-Ag bimetallic catalysts were also investigated by changing the pretreatment conditions, and it was found that Ag reappeared at the surface, further increasing the catalytic activity. The results were explained in terms of rearrangement of the most active metallic particles, namely clean particles of pure Pd next to dispersed Ag particles [92].

\section{Effects of different atmospheres}

Different applications require different CO oxidation catalysts to be designed and developed. Investigation of the effects of different environmental atmospheres on the catalytic activity for $\mathrm{CO}$ oxidation at low temperatures not only gives insights into the catalytic reaction mechanism, but is also of great importance for catalyst development. The presence of other components in the $\mathrm{CO}$ feed, such as $\mathrm{H}_{2}$, water, and $\mathrm{CO}_{2}$, affect the activity for $\mathrm{CO}$ oxidation.

\subsection{Effect of $\mathrm{H}_{2}$}

It is known that a small amount of $\mathrm{CO}$ in $\mathrm{H}_{2}$ strongly affects the performance of $\mathrm{Pt}$ anodes and fuel-cells, and it is essential to remove traces of $\mathrm{CO}$ from the $\mathrm{H}_{2}$ feed gas. A large number of studies of $\mathrm{Ag}$ catalysts for $\mathrm{CO}$ selective oxidation in $\mathrm{H}_{2}$ have been performed, but the selectivities were too low. We prepared different $\mathrm{Ag} / \mathrm{SiO}_{2}$ catalysts [30,95-99], but the maximum CO conversion was $60 \%$, and the selectivity was not more than $40 \%$. Derekayal et al. [49] reported that 100\% CO conversion over a Ag/Co/Ce catalyst was achieved at $150{ }^{\circ} \mathrm{C}$. The selectivity was very low $(<20 \%)$ and the low-temperature $\left(<80^{\circ} \mathrm{C}\right)$ activity was also poor. Chen et al. $[100,101]$ reported that Ag supported on active carbon can achieve 100\% CO conversion at $100{ }^{\circ} \mathrm{C}$, but the selectivity was again very low $(<20 \%)$. In contrast, Ag-Co and Ag-Mn catalysts showed higher selectivities, but the temperature for complete $\mathrm{CO}$ conversion was high
[102,103]. Hu et al. [103] reported that $100 \%$ CO conversion can be maintained for $250 \mathrm{~h}$ at $120^{\circ} \mathrm{C}$, with about $90 \%$ selectivity.

\subsection{Effect of water}

Water is inevitably present in various environments, but, so far, the effects of water on the performance of Ag catalysts have rarely been studied. Studies showed that water vapor at the parts per million $\left(10^{-6}\right)$ level in the feed had a positive effect on the catalytic activity [55,104,105]. A small amount of water could prevent carbonate formation on the surfaces of Ag catalysts, resulting in increased catalytic activity for CO oxidation $[55,104]$. Moreover, Su et al. [105] reported that adsorbed water affects not only the adsorption of reactants but also the transition states and intermediates. The formation of hydrogen bonds as a result of adsorption of water facilitates the dissociation of $\mathrm{O}_{2}$. The formed atomic oxygen can further react with the adsorbed water to form hydroxyls, which promotes $\mathrm{CO}$ oxidation. However, there is still a lack of systematic data regarding the effect of water on catalytic performance for $\mathrm{CO}$ oxidation at low temperatures; this needs to be further investigated in the near future.

\section{7. $\mathrm{CO}$ and $\mathrm{O}_{2}$ adsorption processes and reaction mechanisms}

\section{1. $\mathrm{CO}$ and $\mathrm{O}_{2}$ adsorption processes}

The adsorption of $\mathrm{CO}$ and $\mathrm{O}_{2}$ on the surface of $\mathrm{Ag}$ catalysts is of interest in many research areas, such as physical chemistry and surface science. Research on the adsorption of $\mathrm{CO}$ and $\mathrm{O}_{2}$ is very helpful in understanding the activation processes of $\mathrm{CO}$ and $\mathrm{O}_{2}$, the role of $\mathrm{Ag}$, and the intrinsic character of the surface reactions and catalytic process. So far, most studies have focused on theoretical calculations and catalyst models [106-127].

Zhou and Hagen et al. [107-112] reported that the adsorption of CO on top sites, among various possible sites, was energetically preferred, based on DFT calculations and temperature-dependent gas-phase kinetic data. CO easily reacted with Ag clusters with adsorbed oxygen species. In addition, B3LYP DFT has been used to study the electronic and geometric structures of Ag anion dimers bonded with $\mathrm{CO}$ and oxygen. It appears that $\mathrm{CO}$ oxidation can be achieved, cost effectively, at room temperature using Ag without any external supply of energy [113]. Moreover, ultraviolet photoelectron spectroscopy showed that $\mathrm{O}_{2}$ partially dissociated on $\mathrm{Ag}_{2}{ }^{-}$, and these dissociative chemisorptions were a kinetically hindered step [114]. Recently, it was found that there were four possible reaction pathways for $\mathrm{CO}$ oxidation catalyzed by $\mathrm{Ag}_{2}-$ [115]. The most feasible pathway was $\mathrm{CO}$ insertion into the $\mathrm{Ag}-\mathrm{O}$ bond of $\mathrm{Ag}_{2} \mathrm{O}_{2}-$ to produce an intermediate, $\left[\mathrm{Ag}-\mathrm{AgC}(\mathrm{O}-\mathrm{O}) \mathrm{O}^{-}\right.$, and then the intermediate decomposed to the products $\mathrm{CO}_{2}$ and $\mathrm{Ag}_{2} \mathrm{O}^{-}$, or another $\mathrm{CO}$ molecule attacked $[\mathrm{Ag}-\mathrm{AgC}(\mathrm{O}-\mathrm{O}) \mathrm{O}]^{-}$to form two $\mathrm{CO}_{2}$ molecules and an $\mathrm{Ag}_{2}{ }^{-}$anion.

The adsorption behavior of $\mathrm{CO}$ and $\mathrm{O}_{2}$ on different Ag crystal 
faces has also been investigated using X-ray photoelectron spectroscopy, scanning tunneling microscopy, and theoretical calculation methods. The results showed that $\mathrm{CO}$ on an $\mathrm{Ag}(001)$ surface tended to react with surface 0 atoms [116]. The most feasible pathway is $\mathrm{CO}+\mathrm{O}_{2} \rightarrow \mathrm{O}_{2} \cdots \mathrm{CO} \rightarrow \mathrm{CO}_{2}+\mathrm{O}$ [117]. Burghaus et al. $[118,119]$ reported that $\mathrm{CO}$ tended to react with molecularly adsorbed oxygen on the Ag(110) surface below the dissociation temperature of molecularly bonded oxygen. However, only weakly adsorbed CO species were observed on the surface of $\mathrm{Ag}(111)$ under high pressure and at low temperatures [120]; this is consistent with the results of Schmeisser et al. [121] and Jänsch et al. [122]. Hammer et al. [123] and Jiang et al. [124] found that CO molecules were dissociatively adsorbed on the surface of Ag single-crystals.

\subsection{CO oxidation reaction mechanisms}

It has been reported that the mechanism for $\mathrm{CO}$ oxidation on Ag catalysts differs, depending on the supports. There are different rate-limiting steps for $\mathrm{CO}$ oxidation on $\mathrm{Ag} / \mathrm{SiO}_{2}$ catalysts in different reaction temperature regions [54]. At low reaction temperatures, oxygen dissociation is the rate-limiting step and occurs easily on fine Ag nanoparticles; however, at high reaction temperatures, oxygen is easily thermally activated and reversible $\mathrm{CO}$ adsorption on the Ag surface becomes the rate-limiting step. It was found that reduction of $\mathrm{Ag}^{+}$on a $\mathrm{Ag} / \mathrm{NaY}$ catalyst was very important for the enhancement of $\mathrm{CO}$ oxidation activity, and the CO oxidation reaction followed first-order reaction kinetics [128].

The CO oxidation mechanism on $\mathrm{Ag}$ on active supports is relatively complicated. The active oxygen on Ag is mainly consumed in the oxidation of $\mathrm{CO}$, and $\mathrm{M}$ ( $\mathrm{Mn}, \mathrm{Co}, \mathrm{Ce}$ ) serves as an oxygen carrier to supply oxygen species to Ag (Fig. 8). Ag reoxidation occurs, releasing oxygen from $\mathrm{M}$ ( $\mathrm{Mn}, \mathrm{Co}, \mathrm{Ce})$ $[60,66,81]$. CO oxidation follows a redox reaction mechanism on $\mathrm{Ag} /$ transition-metal oxide catalysts [72]. At low temperatures, the $\mathrm{CO}$ oxidation reaction on the surface of the catalyst is the rate-determining step, and at higher temperatures, i.e., above $473 \mathrm{~K}$, the $\mathrm{CO}$ adsorption rate on the surface of the catalyst becomes the key step.

\section{Conclusions and prospects}

Supported Ag catalysts have a wide range of applications in low-temperature CO oxidation. Many factors such as preparation method, pretreatment conditions, carriers, and particle

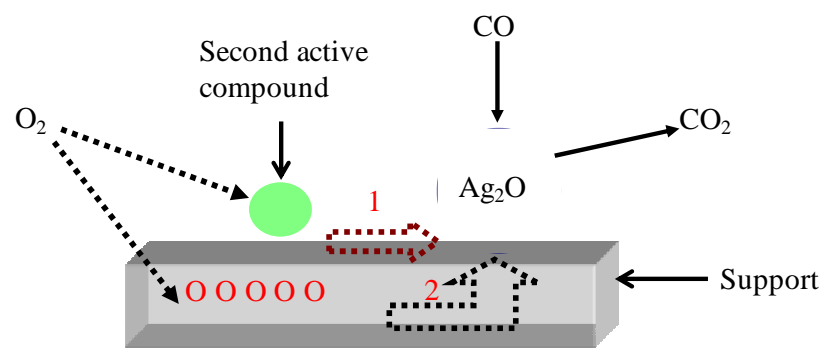

Fig. 8. Possible reaction scheme for $\mathrm{CO}$ oxidation over supported $\mathrm{Ag}$ catalysts (Ag/Co, Mn oxides) [97]. size have important effects on the catalytic activities of supported Ag catalysts. Among the various preparation methods, direct synthetic methods and impregnation methods are the main techniques used to synthesize Ag catalysts that can catalyze CO oxidation at room temperature. Silica materials (such as SBA-15, HMS, or fumed silica) are the best supports for preparing Ag catalysts with high activities by these methods. The preparation of highly active Ag catalysts depends significantly on the pretreatment conditions, including the atmosphere and temperature. There is therefore a synergistic effect between these influencing factors in the preparation of supported Ag catalysts with high activities for CO oxidation.

Three main conclusions can be drawn from investigation of Ag catalysts for CO oxidation. (1) An obvious dependence of catalytic activity on the Ag nanoparticle size can be seen in reactions on inert supports. (2) Different pretreatment atmospheres are required for different supports. For inert supports such as silica, low-temperature $\mathrm{H}_{2}$ treatment after calcination is conducive to $\mathrm{Ag}$ dispersion and improvement of the activity. However, for active supports such as $\mathrm{CeO}_{2}$ and $\mathrm{MnO}_{2}$, calcination is more beneficial in improving the activity. (3) The reaction mechanism is different for Ag on different supports. For inert supports, the adsorption and dissociation of $\mathrm{CO}$ and $\mathrm{O}_{2}$ molecules occur on the Ag surface or at the interface between $\mathrm{Ag}$ and the inert support. The catalytic activities of Ag catalysts are therefore largely dependent on the particle size. For active supports, the lattice oxygens in the support and electron transfer between Ag-oxygen and transition metals play an important role in the catalytic activity. Although researchers have paid much attention to supported Ag catalysts for CO oxidation in recent years, little attention has been given to catalysis in practical industrial atmospheres, and there have been few investigations of the influence of water and $\mathrm{CO}_{2}$ on the structures and catalytic activities of supported Ag catalysts. Furthermore, the reaction mechanism of $\mathrm{CO}$ oxidation over supported Ag catalysts is unclear, and the migration and transformation processes of $\mathrm{CO}$ and $\mathrm{O}_{2}$ on the catalyst surface need to be studied in detail using in-situ techniques. With further investigation, we believe that supported Ag catalysts will be widely used in industry and environmental protection (including air purification in tunnels and indoors) in the near future.

\section{References}

[1] Gardner S D, Hoflund G B, Upchurch B T, Schryer D R, Kielin E J, Schryer J. J Catal, 1991, 129: 114

[2] Haruta M. Catal Today, 1997, 36: 153

[3] Amphlett J C, Mann R F, Peppley B A. Int J Hydrogen Energy, 1996, 21: 673

[4] Recupero V, Pino L, Cordaro M, Vita A, Cipitì F, Laganà M. Fuel Process Technol, 2004, 85: 1445

[5] Ahluwalia R K, Zhang Q, Chmielewski D J, Lauzze K C, Inbody M A. Catal Today, 2005, 99: 271

[6] Fierro G, Morpurgo S, Jacono M L, Inversi M, Pettiti I. Appl Catal A, 1998, 166: 407

[7] Haruta M. Catal Surv Jpn, 1997, 1: 61

[8] Bond G C, Thompson D T. Catal Rev-Sci Eng, 1999, 41: 319

[9] Hao Z P, An L D, Wang H L. J Mol Catal (China) (郝郑平, 安立敦, 
王弘立. 分子催化), 1996, 10: 235

[10] Kung H H, Kung M C, Costello C K. J Catal, 2003, 216: 425

[11] Grisel R, Weststrate K J, Gluhoi A, Nieuwenhuys B E. Gold Bull, 2002, 35: 39

[12] Thompson D. Gold Bull, 1998, 31: 111

[13] Wang D H, Cheng D Y, Hao Z P, Shi X C. Progr Chem (王东辉, 程代 云, 郝郑平, 史喜成. 化学进展), 2002, 14: 360

[14] Campelo J M, Luna D, Luque R, Marinas J M, Romero A A. ChemSusChem, 2009, 2: 18

[15] Yang X M, Luo L T. Modern Chem Ind (杨小毛, 罗来涛. 现代化 工), 2002, 22(8): 22

[16] Shi S Z. Safety in Coal Mines (施申忠. 煤矿安全), 2002, 33(4): 36

[17] Du F L, Cui Z L, Zhang Z K. J Qingdao Inst Chem Technol (杜芳林, 崔作林, 张志琨. 青岛化工学院学报), 1999, 20: 29

[18] Wang Y Z, Zhao Y X, Liu D S. Tech Equip Environ Pollut Control (王 永钊, 赵永祥, 刘滇生. 环境污染治理技术与设备), 2003, 4(8): 8

[19] Zheng X C, Wang X Y, Yu L H, Wang S R, Wu S H. Progr Chem (郑 修成, 王向宇, 于丽华, 王淑荣, 吴世华. 化学进展), 2006, 18: 159

[20] Yu Q, Gao F, Dong L. Chin J Catal (余强, 高飞, 董林. 催化学报), 2012, 33: 1245

[21] van Santen R A, Kuipers H P C E. Adv Catal, 1987, 35: 265

[22] Nagy A J, Mestl G, Schlögl R.J Catal, 1999, 188: 58

[23] Shi C, Cheng M J, Qu Z P, Bao X H.J Mol Catal A, 2005, 235: 35

[24] Bao X H, Muhler M, Schedel-Niedrig T, Schlögl R. Phys Rev B, 1996, 54: 2249

[25] Liu H Y, Ma D, Blackley R A, Zhou W Z, Bao X H. Chem Commun, 2008: 2677

[26] Qu Z P, Zhang X D, Chen D, Li X Y, Wen M, Wang Y, Ma D, Wu J J. Chem J Chin Univ (曲振平, 张晓东, 陈丹, 李新勇, 闻梦, 王奕, 马丁, 吴晶晶. 高等学校化学学报), 2011, 32: 1605

[27] Zhang X D, Qu Z P, Li X Y, Wen M, Quan X, Ma D, Wu J J. Sep Purif Technol, 2010, 72: 395

[28] Vilchis-Nestor A R, Avalos-Borja M, Gómez S A, Hernández J A, Olivas A, Zepeda T A. Appl Catal B, 2009, 90: 64

[29] Xia G G, Yin Y G, Willis W S, Wang J Y, Suib S L. J Catal, 1999, 185: 91

[30] Qu Z P, Cheng M J, Dong X L, Bao X H. Catal Today, 2004, 93-95: 247

[31] Shimizu K I, Sawabe K I, Satsuma A. ChemCatChem, 2011, 3: 1290

[32] Bera P, Patil K C, Hegde M S. Phys Chem Chem Phys, 2000, 2: 3715

[33] Chen J L, Li J, Li H J, Huang X M, Shen W J. Microporous Mesoporous Mater, 2008, 116: 586

[34] Yin J Z, Zhang C J, Xu Q Q, Wang A Q. J Inorg Mater (银建中, 张传 杰, 徐琴琴, 王爱琴. 无机材料学报), 2009, 24: 129

[35] Huang M H, Choudrey A, Yang P D. Chem Commun, 2000: 1063

[36] Tu C H, Wang A Q, Zheng M Y, Meng Y, Shan J X, Zhang T. Chin J Catal (涂彩华, 王爱琴, 郑明远, 孟云, 单继宏, 张涛. 催化学报), 2005, 26: 631

[37] Yen C W, Lin M L, Wang A Q, Chen S A, Chen J M, Mou C Y.J Phys Chem C, 2009, 113: 17831

[38] Liu X Y, Wang A Q, Yang X F, Zhang T, Mou C Y, Su D S, Li J. Chem Mater, 2009, 21: 410

[39] Zhang X D, Qu Z P, Li X Y, Zhao Q D, Zhang X, Quan X. Mater Lett, 2011, 65: 1892

[40] Zhang X D, Qu Z P, Li X Y, Zhao Q D, Wang Y, Quan X. Catal Commun, 2011, 16: 11

[41] Zhu W P, Han Y C, An L J. Microporous Mesoporous Mater, 2005, 80: 221

[42] Tian D, Yong G P, Liu S M. Sci Sin Chim (田冬, 雍国平, 刘少民. 中 国科学: 化学), 2011, 41:828

[43] Tian D, Yong G P, Dai Y, Yan X Y, Liu S M. Catal Lett, 2009, 130: 211

[44] Lin R, Liu W P, Zhong Y J, Luo M F. Appl Catal A, 2001, 220: 165
[45] Chen M, Zheng X M. Environ Chem (陈敏, 郑小明. 环境化学), 2000, 19: 110

[46] Chen M, Luo M F, Zheng X M. Chin J Appl Chem (陈敏, 罗孟飞, 郑 小明. 应用化学), 1999, 16: 50

[47] Chen M, Zheng X M, Xie Y Q. Petrochem Technol (陈敏, 郑小明, 谢玉群. 石油化工), 2000, 29: 914

[48] Gulari E, Güldür Ç, Srivannavit S, Osuwan S. Appl Catal A, 1999, 182: 147

[49] Derekaya F B, Güldür Ç. Int J Hydrogen Energy, 2010, 35: 2247

[50] Sandoval A, Aguilar A, Louis C, Traverse A, Zanella R. J Catal, 2011, 281: 40

[51] Dai Y M, Pan T C, Liu W J, Jehng J M. Appl Catal B, 2011, 103: 221

[52] Zhang X D, Qu Z P, Yu F L, Wang Y.J Catal, 2013, 297: 264

[53] Zhang X D, Qu Z P, Yu F L, Wang Y, Zhang X. J Mol Catal A, 2013, 370: 160

[54] Jin L, Qian K, Jiang Z Q, Huang W X. J Mol Catal A, 2007, 274: 95

[55] Afanasev D S, Yakovina O A, Kuznetsova N I, Lisitsyn A S. Catal Commun, 2012, 22: 43

[56] Gac W, Derylo-Marczewska A, Pasieczna-Patkowska S, Popivnyak N, Zukocinski G.J Mol Catal A, 2007, 268: 15

[57] Qu Z P, Huang W X, Cheng M J, Bao X H. J Phys Chem B, 2005, 109: 15842

[58] Gac W. Appl Catal B, 2007, 75: 107

[59] Yu L B, Shi Y Y, Zhao Z, Yin H B, Wei Y C, Liu J, Kang W B, Jiang T S, Wang A L. Catal Commun, 2011, 12: 616

[60] Luo M F, Chen M, Zhou L H, Yuan X X. Chin J Catal (罗孟飞, 陈敏, 周烈华, 袁贤金鋾. 催化学报), 1995, 16: 494

[61] Frey K, Iablokov V, Melaet G, Guczi L, Kruse N. Catal Lett, 2008, 124: 74

[62] Comsup N, Panpranot J, Praserthdam P. Catal Lett, 2009, 133: 76

[63] Comsup N, Panpranot J, Praserthdam P. Catal Commun, 2010, 11 : 1238

[64] Comsup N, Panpranot J, Praserthdam P. J Ind Eng Chem, 2010, 16 : 703

[65] Lin R, Liu W P, Zhong Y J, Luo M F. React Kinet Catal Lett, 2001, 72: 289

[66] Imamura S, Sawada H, Uemura K, Ishrda S. J Catal, 1988, 109: 198

[67] Parida K M, Sahoo A K, Das N N. J Colloid Interface Sci, 1998, 200: 249

[68] Xu R, Wang X, Wang D S, Zhou K B, Li Y D. J Catal, 2006, 237: 426

[69] Song K S, Kang S K, Kim S D. Catal Lett, 1997, 49: 65

[70] Zhong Y J, Wu X H, Luo M F. Bull Sci Technol (钟依均, 吴小华, 罗 孟飞. 科技通报), 1997, 13(1): 6

[71] Zhong Y J, Wu X H, Zhou L H, Luo M F. Modern Chem Ind (钟依均, 吴小华, 周烈华, 罗孟飞. 现代化工), 1997, 17(2): 25

[72] Hu R R, Cheng Y, Ding Y L, Xie L Y, Wang D Z. Acta Chim Sin (胡蓉 蓉, 程易, 丁宇龙, 谢兰英, 王德峥. 化学学报), 2007, 65: 2001

[73] Hu R R, Cheng Y, Xie L Y, Wang D Z. Chin J Catal (胡蓉蓉, 程易, 谢兰英, 王德峥. 催化学报), 2007, 28: 463

[74] Hu R R, Xie L Y, Ding S, Hou J, Cheng Y, Wang D Z. Catal Today, 2008, 131: 513

[75] Hiyoshi N, Ikeda T, Kato M. Chem Lett, 2011, 40: 480

[76] Su D S, Jacob T, Hansen T W, Wang D, Schlögl R, Freitag B, Kujawa S. Angew Chem, Int Ed, 2008, 47: 5005

[77] Qu Z P, Huang W X, Zhou S T, Zheng H, Liu X M, Cheng M J, Bao X H. J Catal, 2005, 234: 33

[78] Luo M F, Yuan X X, Zheng X M. Appl Catal A, 1998, 175: 121

[79] Lim D C, Lopez-Salido I, Kim Y D. Surf Sci, 2005, 598: 96

[80] Zhang H P, Ye L Y.J Xiamen Univ (Nat Sci) (张会平, 叶李艺. 厦门 大学学报(自然科学版)), 2002, 41: 71

[81] Luo M F, Yuan X X. Chin J Catal (罗孟飞, 袁贤釒催化学报), 1995, 16: 328

[82] Luo M F, Zhu B, Zhou R X, Jiang X Y, Yuan X X. Environ Chem (罗孟 


\title{
Graphical Abstract
}

Chin. J. Catal., 2013, 34: 1277-1290 doi: 10.1016/S1872-2067(12)60610-X

\section{Progress in carbon monoxide oxidation over nanosized Ag catalysts}

ZHANG Xiaodong, QU Zhenping*, YU Fangli, WANG Yi

Dalian University of Technology

ecent developments of Ag catalysts for $\mathrm{CO}$ oxidation mainly focus on the structures of Ag catalysts (particle size, species states, etc.) and their catalytic activities.

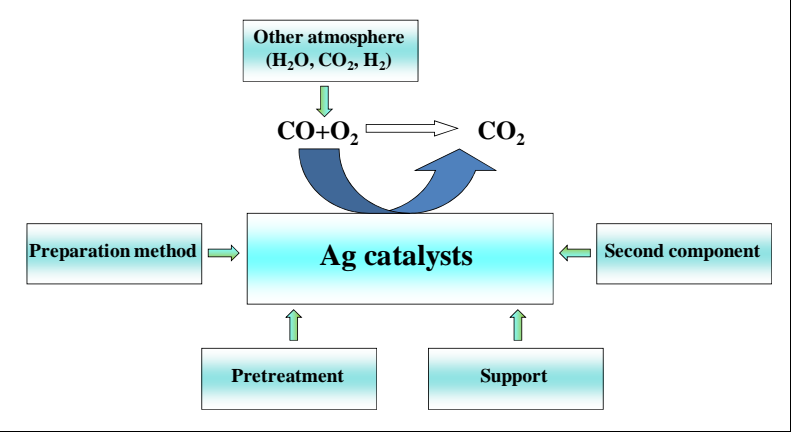

飞, 朱波, 周仁贤, 蒋晓原, 袁贤釒金. 环境化学), 1996, 15: 193

[83] Luo M F, Zhou L H, Zhu B, Chen M, Yuan X X. J Mol Catal (China) (罗孟飞, 周烈华, 朱波, 陈敏, 袁贤金. 分子催化), 1995, 9: 285

[84] Wang A Q, Liu J H, Lin S D, Lin T S, Mou C Y. J Catal, 2005, 233: 186

[85] Wang A Q, Heish Y P, Chen Y F, Mou C Y.J Catal, 2006, 237: 197

[86] Wang A Q, Chang C M, Mou C Y.J Phys Chem B, 2005, 109: 18860

[87] Liu J H, Wang A Q, Chi Y S, Lin H P, Mou C Y. J Phys Chem B, 2005, 109: 40

[88] Wang L C, Zhong Y, Widmann D, Weissmueller J, Behm R J. ChemCatChem, 2012, 4: 251

[89] Kim H Y, Kim D H, Ryu J H, Lee H M. J Phys Chem C, 2009, 113: 15559

[90] Chou J P, Pai W W, Kuo C C, Lee J D, Lin C H, Wei C M. J Phys Chem C, 2009, 113: 13151

[91] Iizuka Y, Miyamae T, Miura T, Okumura M, Daté M, Haruta M. J Catal, 2009, 262: 280

[92] Venezia A M, Liotta L F, Deganello G, Schay Z, Horváth D, Guczi L. Appl Catal A, 2001, 211: 167

[93] Jaatinen S, Salo P, Alatalo M, Kokko K. Surf Sci, 2004, 566-568: 1063

[94] Politova T I, Gal'vita V V, Belyaev V D, Sobyanin V A. Catal Lett, 1997, 44: 75

[95] Qu Z P, Cheng M J, Shi C, Bao X H. Chin J Catal (曲振平, 程谟杰, 石川, 包信和. 催化学报), 2002, 23: 460

[96] Qu Z P, Zhou S T, Wu W C, Li C, Bao X H. Catal Lett, 2005, 101: 21

[97] Qu Z P, Cheng M J, Huang W X, Bao X H. J Catal, 2005, 229: 446

[98] Qu Z P, Cheng M J, Shi C, Bao X H. J Nat Gas Chem, 2005, 14: 4

[99] Qu Z P, Cheng M J, Shi C, Bao X H. J Mol Catal A, 2005, 239: 22

[100] Chen L M, Ma D, Pietruszka B, Bao X H. J Nat Gas Chem, 2006, 15: 181

[101] Chen L M, Ma D, Bao X H.J Phys Chem C, 2007, 111: 2229

[102] Güldür Ç, Balikçi F. Int J Hydrogen Energy, 2002, 27: 219

[103] Hu R R, Yan C F, Xie L Y, Cheng Y, Wang D Z. Int J Hydrogen Energy, 2011, 36: 64

[104] Wu S X, Yin Y H, Ma Z, Qin Y N. Modern Chem Ind (吴树新, 尹燕 华, 马智, 秦永宁. 现代化工), 2006, 26(6): 33

[105] Su H Y, Yang M M, Bao X H, Li W X. J Phys Chem C, 2008, 112: 17303

[106] Falsig H, Hvolbæk B, Kristensen I S, Jiang T, Bligaard T, Christen- sen C H, Nørskov J K. Angew Chem, Int Ed, 2008, 47: 4835

[107] Zhou J, Li Z H, Wang W N, Fan K N. J Phys Chem A, 2006, 110: 7167

[108] Socaciu L D, Hagen J, Heiz U, Bernhardt T M, Leisner T, Wöste L. Chem Phys Lett, 2001, 340: 282

[109] Socaciu L D, Hagen J, Le Roux J, Popolan D, Bernhardt T M, Wöste L, Vajda S. J Chem Phys, 2004, 120: 2078

[110] Hagen J, Socaciu L D, Le Roux J, Popolan D, Bernhardt T M, Wöste L, Mitrić R, Noack H, Bonačić-Koutecký V. J Am Chem Soc, 2004, 126: 3442

[111] Bernhardt T M, Socaciu-Siebert L D, Hagen J, Wöste L. Appl Catal A, 2005, 291: 170

[112] Bernhardt T M, Hagen J, Lang S M, Popolan D M, Socaciu-Siebert L D, Wöste L. J Phys Chem A, 2009, 113: 2724

[113] Dholabhai P P, Wu X, Ray A K. J Mol Struct Theochem, 2005, 723: 139

[114] Kim Y D, Ganteför G, Sun Q, Jena P. Chem Phys Lett, 2004, 396: 69

[115] Tang T Y, Hu J P, Zhang Y Q Hu C W. Acta Chim Sin (唐典勇, 胡建 平, 张元勤, 胡常伟. 化学学报), 2007, 67: 1859

[116] Savio L, Vattuone L, Rocca M, de Mongeot F B, Comelli G, Baraldi A, Lizzit S, Paolucci G. Surf Sci, 2002, 506: 213

[117] Barth J V, Zambelli T. Surf Sci, 2002, 513: 359

[118] Burghaus U, Conrad H. Surf Sci, 1996, 364: 109

[119] Burghaus U, Conrad H. Surf Sci, 1996, 352-354: 253

[120] McElhiney G, Papp H, Pritchard J. Surf Sci, 1976, 54: 617

[121] Schmeisser D, Greuter F, Plummer E W, Freund H J. Phys Rev Lett, 1985, 54: 2095

[122] Jänsch H J, Huang C, Ludviksson A, Redding J D, Metiu H, Martin R M. Surf Sci, 1989, 222: 199

[123] Hammer B, Morikawa Y, Nørskov J K. Phys Rev Lett, 1996, 76: 2141

[124] Jiang L, Wang G C, Guan N J, Wu Y, Cai Z S, Pan Y M, Zhao X Z, Huang W, Li Y W, Sun Y H, Zhong B. Acta Phys-Chim Sin (江凌, 王 贵昌, 关乃佳, 吴杨, 蔡遵生, 潘荫明, 赵学庄, 黄伟, 李永旺, 孙 予罕, 钟炳. 物理化学学报), 2003, 19: 393

[125] Burghaus U, Conrad H. Surf Sci, 1996, 352-354: 201

[126] Burghaus U, Conrad H. Surf Sci, 1997, 370: 17

[127] Burghaus U, Vattuone L, Gambardella P, Rocca M. Surf Sci, 1997, 374: 1

[128] El-Bahy Z M. Mater Res Bull, 2007, 42: 2170

\section{纳米银催化剂上CO氧化反应研究进展}

\author{
张晓东, 曲振平 ${ }^{*}$, 千芳丽, 王奕 \\ 大连理工大学环境学院, 工业生态与环境工程教育部重点实验室, 辽宁大连116024
}


摘要: 纳米Ag催化剂由于具有独特的物理和化学性质, 在很多反应中受到了越来越多的关注, 尤其对低温催化一氧化碳氧化反 应. 近年来, 银催化剂表现出较高的催化活性、稳定性以及良好的应用前景, 能够在常温下将 $\mathrm{CO}$ 氧化为 $\mathrm{CO}_{2}$. 本文结合本课题组的 研究进展, 从制备方法、载体、预处理、第二组分、其它气氛和催化反应机理等方面对 $\mathrm{Ag}$ 基催化剂上CO氧化反应进行了系统的 讨论和总结.

关键词: 负载型银催化剂; 一氧化碳氧化; 制备方法; 预处理条件

收稿日期: 2013-01-24. 接受日期: 2013-04-27. 出版日期: 2013-07-20.

*通讯联系人. 电话: 15542663636; 传真: (0411)84708083; 电子信箱: quzhenping@dlut.edu.cn

基金来源：新世纪优秀人才支持计划(NCET-09-0256); 国家高技术研究发展计划(863计划, 2009AA062604); 格平绿色助学行动 辽宁环境科研教育“123工程”(CEPF2010-123-1-10).

本文的英文电子版由Elsevier出版社在ScienceDirect上出版(http://www.sciencedirect.com/science/journal/18722067).

\section{1. 前言}

$\mathrm{CO}$ 是许多工业环境和室内环境的主要气体污染物 之一, 易与人体内的血红蛋白结合, 损害人的中枢神经 系统. 目前, 最常用且有效的消除CO的方法是低温催化 氧化法. 而且, 在空气及汽车尾气净化, $\mathrm{CO}_{2}$ 激光器气体 纯化 ${ }^{[1]}, \mathrm{CO}$ 气体传感器 ${ }^{[2]}$, 燃料电池 ${ }^{[3 \sim 5]}$ 等领域也涉及到 $\mathrm{CO}$ 的净化. 另外, 由于 $\mathrm{CO}$ 分子量较小, 氧化反应过程简 单, 常被用作探针分子来研究催化剂的表面结构. 因此, 研究CO的消除在基础研究和实际应用方面都具有重要 的意义.

自 20 世纪八十年代以来, Hopcalite催化剂和以 $\mathrm{Au}$, Pd或Pt为活性组分的贵金属催化剂广泛应用于 $\mathrm{CO}$ 氧化 中. 由于Hopcalite催化剂抗水性差, 贵金属价格昂贵, 限 制了其在工业中的应用 ${ }^{[6]}$. 近年来, 有关金催化CO氧化 的综述很多 ${ }^{[2,7 \sim 14]}$, 而其它用于 $C O$ 氧化的非贵金属催化 剂的综述也见诸报道 ${ }^{[15 ~ 20]}$. 相对廉价的银催化剂在 $\mathrm{NO}_{x}$ 消除, 乙烯环氧化及甲烷氧化等 ${ }^{[21 ~ 23]}$ 反应中都表现出较 好的低温氧化活性. 由于银的 $d$ 轨道电子是完全充满的 (第一电离能 $731 \mathrm{~kJ} / \mathrm{mol}$ (7.58 eV), 电负性1.9), 很难失去 电子, 所以Ag的表面与表面反应物分子之间的相互作用 力很弱. 研究表明, 对银结构进行再构使得 $\mathrm{Ag}(111)$ 面上 形成一个全新的氧物种, 其反应性(如 $\mathrm{CO}$ 氧化)远远高于 表面氧物种 ${ }^{[24]}$. 然而, 有关 $\mathrm{CO}$ 氧化用银催化剂的综述相 对较少. 鉴于近期Ag催化剂研究进展较快, 本文结合本 课题组研究成果, 从制备方法、预处理气氛和温度、载 体、助剂及反应机理等方面, 对 Ag催化剂上CO低温氧化 反应进行系统的总结和讨论, 以期得到一些有意义和价 值的结果, 进一步促进 $\mathrm{CO}$ 低温氧化用银催化剂的研究 与开发.

\section{2. 制备方法的影响}

由于 $\mathrm{Ag}$ 的熔点 $\left(960{ }^{\circ} \mathrm{C}\right)$ 比 $\mathrm{Au}\left(1063{ }^{\circ} \mathrm{C}\right), \operatorname{Pd}\left(1550{ }^{\circ} \mathrm{C}\right)$
和Pt $\left(1769^{\circ} \mathrm{C}\right)$ 的低, 粒子易发生聚集, 因此制备方法的 选择和设计至关重要. 研究表明, $\mathrm{Ag}$ 颗粒的尺寸及分散 度影响它与载体间相互作用力 ${ }^{[25]}$, 从而表现出不同的催 化活性. 因此, 采用不同的制备方法, 可制备出具有不同 活性的负载型银催化剂. 目前应用于 $\mathrm{CO}$ 氧化反应的银

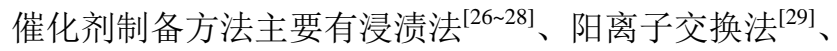
混合法 ${ }^{[30,31] 、}$ 、燃烧法 ${ }^{[32]}$ 、简单固态混合法 ${ }^{[33]}$ 、超临界流

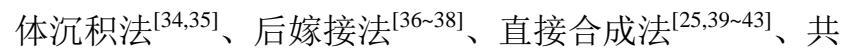
沉淀法 ${ }^{[44 ~ 49]}$ 和沉积-沉淀法 ${ }^{[50,51]}$ 等.

通过改进的浸渍法制备的 $\mathrm{AgAu} / \mathrm{SiO}_{2}-\mathrm{Al}_{2} \mathrm{O}_{3}$ 催化剂 (以虫草菌丝萃取物为还原剂) ${ }^{[28]}$, 与传统的沉积-沉淀法 相比, 该法合成过程简单且制备的粒子小且均一.Xia 等 ${ }^{[29]}$ 以八面体分子篮为载体, 利用阳离子交换法制备了 高分散的纳米银催化剂, 在催化氧化 $\mathrm{CO} 反$ 应较长时间 (1800 min)而不失活. 我们之前 ${ }^{[0]}$ 利用混合法将银粒子 与载体以机械混合的方式进行研磨, 经过一定的处理制 得催化剂, 其中银粒子用氧气于 $500 \sim 700{ }^{\circ} \mathrm{C}$ 处理后表现 出较高的热稳定性, 粒子尺寸远远小于未负载的银粒子. Bera等 ${ }^{[32]}$ 采用燃烧法制备银催化剂, 其中 $\mathrm{Ag}^{+}$高度分散 于 $\mathrm{CeO}_{2}$ 载体上, 从而表现出更高催化活性. Chen等 ${ }^{[33]}$ 采 用简单固态混合法制备了Ag-OMS-2催化剂, 发现 $\mathrm{Ag}^{+}$大 量取代 $\mathrm{K}^{+}$, 形成更多的活性位, 明显提高了吸附CO和活 化氧分子的能力, 催化剂在 $90{ }^{\circ} \mathrm{C}$ 可以完全转化CO.

上述制备方法制得的Ag催化剂虽能获得较好的催 化活性, 但银粒子在随后的活化及反应过程中仍然很容 易发生聚集, 从而导致活性降低. 最近, 人们发现有序介 孔硅材料的孔道限域作用可大大提高 $\mathrm{Ag}$ 纳米粒子的热 稳定性. 银建中等 ${ }^{[34]}$ 采用超临界流体沉积法制备了 Ag/SBA-15催化剂. 该方法利用超临界流体表面张力为 零的特点, 使得银前驱体更易扩散到多孔狭缝之中形成 小的Ag粒子. 但由于共溶剂的加入显著提高了硝酸银 在超临界 $\mathrm{CO}_{2}$ 中的溶解度, 在孔道内很容易形成纳米线, 而这些纳米线并不利于提高反应活性, 该反应 $300{ }^{\circ} \mathrm{C}$ 时 
CO才能完全转化. 涂彩华等 ${ }^{[36]}$ 通过后嫁接法(图1), 利 用SBA-15的规则孔道限域组装, 在孔道内形成了高分散 的银粒子, 表现出较高的催化CO活性. Yen等 ${ }^{[37]}$ 也采用 相同的方法对 $\mathrm{Au}-\mathrm{Ag}$ 合金粒子进行可控组装, 所得催化 剂 $\mathrm{CO}$ 在 $30{ }^{\circ} \mathrm{C}$ 可完全转化. 最近, $\mathrm{Liu}$ 等 ${ }^{[38]}$ 以商业 $\mathrm{SiO}_{2}$ 为 载体, 采用后嫁接法合成了高度分散且热稳定性高的 $\mathrm{Au}-\mathrm{Ag}$ 合金粒子, 催化CO完全转化温度降至 $0{ }^{\circ} \mathrm{C}$, 但该 法存在的最大问题是制备过程复杂, 需要无水无氧, 条 件苛刻.

直接合成法因其合成过程简单而备受关注. 针对银 在合成SBA-15的强酸溶液中很难负载的问题, 本课题组 采用调节 $\mathrm{pH}$ 的方法在中性溶液中制备出高负载量 $(7.9$ $w t \%)$ 的Ag/SBA-15催化剂 ${ }^{[39,40]}$. 所得催化剂负载量和催 化CO氧化性能较之前 ${ }^{[41 ~ 43]}$ 都有大幅度的提高(图2). 此 外, Liu等 ${ }^{[25]}$ 利用模板剂十二胺来保护还原过程的银, 制 备了高分散的银纳米粒子, 使其催化 $\mathrm{CO}$ 氧化性能大幅 度提高, 其完全转化温度降至 $30{ }^{\circ} \mathrm{C}$ (见图3).

\section{3. 预处理的影响}

焙烧是制备负载型银催化剂的必要过程. 样品经过 焙烧和活化处理后, 纳米银与载体之间可产生一定的相 互作用. 将银纳米粒子与 $\mathrm{SiO}_{2}$ 物理性的机械混合, 活性 很低, 但如果 $\mathrm{O}_{2}$ 一定温度的焙烧, 活性会显著增加 ${ }^{[30]}$. 最近, Shimizu等 ${ }^{[31]}$ 将银粒子与载体 $\mathrm{Al}_{2} \mathrm{O}_{3}$ 机械混合制备 了 $\mathrm{Ag} / \mathrm{Al}_{2} \mathrm{O}_{3}$ 催化剂, 发现催化剂在经高温空气 $\left(1000{ }^{\circ} \mathrm{C}\right)$ 处理后, 银与载体相互作用形成的更多银簇有利于 $\mathrm{CO}$ 氧化, 进一步证实了温度诱导或反应诱导引起的银催化 剂结构再构是设计具有高活性和高稳定性催化剂的关 键步骤.

最近, 本课题组 ${ }^{[52]}$ 首次利用氧气高温 $\left(900{ }^{\circ} \mathrm{C}\right)$ 处理 及SBA-15的孔道, 采用等体积浸渍法制备出低担载量 (1.4 wt\%)高活性的CO催化氧化催化剂 $\left(T_{98}=20^{\circ} \mathrm{C}\right)$, 并 提出了高温氧气处理导致蒸发-沉积-诱导的模型(图4). 在此过程中, 氧吸附质在 $900{ }^{\circ} \mathrm{C}$ 下能够降低催化剂的表 面自由能, 从而使得蒸发的银原子重新沉积在催化剂表 面; 同时, 银在孔道及气氛的作用下被诱导进入SBA-15 孔道内, 形成高分散的小尺寸银粒子. 此外, 我们 ${ }^{[33]}$ 还 发现, 预处理气氛和银负载量均对Ag/SBA-15催化剂的 结构和活性影响非常大(图5). 当银负载量为 $2 \mathrm{wt} \%$ 时, $\mathrm{Ar}$ 处理有利于得到高分散的小的银粒子; 至 $8 \mathrm{wt} \%$ 时, $\mathrm{O}_{2}$ 处理有利于形成高分散的小的银粒子. 我们认为, 当 银负载量较低时, 小尺寸的银粒子有利于催化反应活性
的提高; 而当银负载量较高时, 催化剂再构所形成的次 表层氧是催化剂获得高活性的关键因素.

Jin等 ${ }^{[54]}$ 研究发现, 在 $\gamma$ 射线照射过程中, 银离子被还 原成金属银, 与焙烧处理的 $\mathrm{Ag} / \mathrm{SiO}_{2}$ 催化剂相比, 经 $\gamma$ 射 线照射处理的银物种以金属态存在, 而且生成的粒子较 小. 在 $\mathrm{CO}$ 氧化反应中表现出较低的低温活性和较高的 高温活性. 不同的预处理过程导致了不同的银物种, 相 应表现出不同的催化CO氧化活性. 其次, 研究者还发 现, 负载银的载体不同, 所得催化剂所需预处理条件也 不同. 在氧化硅载体上, 焙烧处理后低温氢气还原一般 有利于活性的提高 ${ }^{[25 ~ 27,42,55,56]}$. 我们 ${ }^{[57]}$ 也发现, 高温氧 气处理使银催化剂表面发生再构, 同时也在银的体相中 形成了大量的次表层氧物种. 随后的 $\mathrm{H}_{2}$ 低温还原有利于 银粒子的再分散, 形成了更多小的银粒子, 从而提高了 其催化活性(图6).

而对于氧化铈 ${ }^{[32]}$ 和氧化锰 ${ }^{[58]}$ 等载体, 焙烧处理有利 于其负载 $\mathrm{Ag}$ 催化活性的提高, 随后的 $\mathrm{H}_{2}$ 处理可生成更多 的银, 但同时也影响了载体结构, 因而催化剂活性降低. 这主要是由于载体本身也具有一定的催化 $\mathrm{CO}$ 氧化活性. $\mathrm{Gac}^{[58]}$ 考察了预处理气氛对 $\mathrm{Ag} / \mathrm{MnO}_{x}$ 催化剂结构和活性 的影响, 发现焙烧后催化剂表面形成了大量的活性氧物 种 $(\mathrm{Mn}-\mathrm{O})$, 经 $\mathrm{H}_{2}$ 还原后, 催化剂上 $\mathrm{Ag}_{2} \mathrm{O}$ 消失的同时也破 坏了 $\mathrm{Mn}$ 结构, 从而导致催化剂的低温活性降低; 但由于 还原使得锰氧化物形成了新的活性位点, 又提高了催化 剂的高温活性. 对于含有银的双组分催化剂, 均需用 $\mathrm{H}_{2}$ 高温还原处理 ${ }^{[37,38]}$ (图7). 使得 $\mathrm{Ag}_{2} \mathrm{O}$ 还原以及再构形成 合金粒子, 从而提高了催化剂对 $\mathrm{CO}$ 氧化的催化活性.

\section{4. 载体的影响}

研究表明, 负载型银催化剂活性远远高于未负载的. 这主要是由于载体能够分散银粒子, 同时两者间能产生 一定的相互作用 ${ }^{[25]}$. 用于负载银催化剂的氧化物载体 主要分为两类: (1)惰性载体, 例如 $\mathrm{SiO}_{2}{ }^{[25 ~ 27,42,52,53,55,56,59]}$ 和 $\mathrm{Al}_{2} \mathrm{O}_{3}{ }^{[600}$ 等; (2)活性载体, 即载体自身能够活化反应 分子而使之发生反应, 例如 $\mathrm{CeO}_{2}{ }^{[32]}, \mathrm{FeO}_{x}{ }^{[45 \sim 47]}, \mathrm{CoO}_{x}{ }^{[48]}$, $\mathrm{TiO}_{2}{ }^{[61 \sim 64]}$ 和 $\mathrm{MnO}_{x}{ }^{[29,58,65 \sim 69]}$ 等. 不同载体负载的银催化 剂上CO氧化反应活性如表1所示.

前面有关预处理气氛以及制备方法中, 我们已经介 绍了很多硅基材料负载的 $\mathrm{Ag}$ 催化剂对 $\mathrm{CO}$ 的催化氧化活 性. 与 $\mathrm{Au}$ 催化剂不同, 氧化硅负载的Ag催化剂表现出很 高的催化 CO 氧化活性, $\mathrm{CO}$ 在常温即可完全转化 ${ }^{[25,55]}$. 下文着重介绍各载体负载的银催化剂以及不同载体导 
致的不同的CO催化氧化活性物种.

钟依均等 ${ }^{[70,71]}$ 运用 $X$ 射线衍射(XRD), 程序升温脱 附(TPD) 和程序升温还原 (TPR) 技术研究了 $\mathrm{Ag} / \mathrm{Al}_{2} \mathrm{O}_{3}$, $\mathrm{Ag} / \mathrm{CeO}_{2}$ 和 $\mathrm{Ag} / \mathrm{TiO}_{2}$ 催化剂的氧性质及 $\mathrm{CO}$ 氧化活性, 发 现 $\mathrm{Ag} / \mathrm{Al}_{2} \mathrm{O}_{3}$ 催化剂上 $\mathrm{CO}$ 氧化活性最高, 催化剂上CO氧 化活性顺序与其还原易难顺序一致. Comsup等 ${ }^{[62]}$ 发现, $\mathrm{Ag}$ 与 $\mathrm{TiO}_{2}$ 间很强的相互作用有利于催化活性的提高. $\mathrm{P}$ 和 $\mathrm{Si}$ 对 $\mathrm{TiO}_{2}$ 进行掺杂可导致不同的活性 ${ }^{[63,64]}$. 研究发现, $\mathrm{P}$ 进入 $\mathrm{TiO}_{2}$ 晶格形成 $\mathrm{Ti}-\mathrm{O}-\mathrm{P}$ 键使得载体比表面积和银分 散度提高, 而催化剂对氧的吸附能力取决于 $\mathrm{P}$ 源; 而 $\mathrm{Ti}-\mathrm{O}-\mathrm{Si}$ 键的形成抑制了 $\mathrm{TiO}_{2}$ 晶粒的聚集, 同时促进了 活性氧物种的形成, 加快了晶格氧的移动, 从而导致活 性提高. CO在Ag掺杂的氧化锰八面体分子篮(OMS-2) 表面发生化学吸附, 并与晶格氧反应生成 $\mathrm{CO}_{2} ; \mathrm{XRD}$ 结 果表明, 合成的OMS-2材料属于锰钾矿一维隧道结构, 适量Ag的掺杂改善了分子篮的有序性, 比表面积更高, 孔径更均一 ${ }^{[72 \sim 4]}$. 丝光沸石中Co 与银离子之间存在的 协同作用有利于催化活性的提高 ${ }^{[75]}$.

此外, 不同载体负载的银催化剂上 $\mathrm{CO}$ 氧化反应机 理也不同. 对于惰性载体, $\mathrm{CO}$ 和 $\mathrm{O}_{2}$ 分子的吸附和解离过 程发生在 $\mathrm{Ag}$ 表面或 $\mathrm{Ag}$-载体界面上, 因此其反应活性与 银粒子的尺寸有很大关系 ${ }^{[57,76]}$. 由于Ag的塔曼温度(344 ${ }^{\circ} \mathrm{C}$ )很低, 与 $\mathrm{Au}$ 的性质有所不同, 目前研究还未发现类似 于金催化活性与粒径之间的关系. 本课题组研究表明, 3 5 nm 的银粒子表现出较高的催化活性 ${ }^{[27]}$, 通常认为 $\mathrm{Ag}^{0}$ 是活性物种 ${ }^{[27]}$. 由于 $\mathrm{Ag}$ 很容易与 $\mathrm{SiO}_{2}$ 表面羟基发生 相互作用形成高分散的银粒子, 因此, 我们通过在不同 温度焙烧处理载体表面羟基, 制备出不同粒径的银催化 剂 ${ }^{[77]}$. 对于活性载体, 载体的晶格氧以及银-氧-过渡金 属之间的电子传递对于催化活性起着至关重要的作 用 ${ }^{[29]}$, 具体的活性物种还存在争议. Luo等 ${ }^{[78]}$ 研究认为, $\mathrm{Ag}_{2} \mathrm{O}$ 是活性物种.

近年来人们还尝试使用非氧化还原载体如石墨 ${ }^{[79] 、}$ 活性炭 ${ }^{[51,80]}$ 等. Lim等 ${ }^{[79]}$ 发现, 负载在石墨上的Ag催化 剂活性与银粒子上形成的氧物种有关. 当银粒子大于 3 $\mathrm{nm}$ 时, 在银上形成两种氧物种, 其中一种能够很容易在 常温下与 $\mathrm{CO}$ 反应生成 $\mathrm{CO}_{2}$, 此时催化活性随粒子尺寸的 减少而增加; 但当银粒子小于 $3 \mathrm{~nm}$ 时, 仅在银表面形成 一种氧物种, 而这种氧物种只和气相氧结合, 不与 $\mathrm{CO}$ 反 应. Dai等 ${ }^{[51]}$ 发现, 碳纳米管含氧基团可更好地针合和分 散银纳米粒子, 并表现出较好的低温催化活性. 因此, 载 体对银粒子尺寸及其氧物种形成的影响很大, 从而强烈
地影响着催化活性.

\section{5. 第二组分的影响}

银催化剂因其良好的吸附 $\mathrm{O}_{2}$ 能力而广泛应用于 $\mathrm{CO}$ 氧化反应中. 目前国内外对银催化剂的研究主要集中在 银的结构及活性. 然而, 单组分银催化剂仍然存在一些 无法避免的弊端, 如负载量高, 低温活性差等. 基于此, 人们对银催化剂进行改性, 如加入助剂或采用双金属催 化体系(如 $\mathrm{Au}-\mathrm{Ag}$ 和Pd-Ag等).

\section{1. 助剂的加入}

添加助剂能够改变银催化剂的电子结构, 改变催化 剂的表面性质或对反应物分子的吸附能力; 此外, 还能 够稳定银纳米颗粒, 提高其分散度.

罗孟飞等 ${ }^{[60,81 ~ 83]}$ 考察了添加 $\mathrm{MnO}_{x}, \mathrm{CoO}_{x}$ 或 $\mathrm{CeO}_{2}$ 后 $\mathrm{Ag} / \gamma-\mathrm{Al}_{2} \mathrm{O}_{3}$ 催化剂的活性, 发现这些助剂的加入有助于 催化剂表面氧的吸附和恢复, 从而提高活性. 此外, 他们 还发现 ${ }^{[81]}$, Ce的加入有利于银粒子的分散, 随着 $\mathrm{CeO}_{2}$ 的 加入, $\mathrm{Ag}_{2} \mathrm{O}$ 增多, 但是文中没有建立构性关系. 我们也 发现 ${ }^{[26]}$, 适量的 $\mathrm{CeO}_{2}$ 有利于金属银粒子的分散, 并且在 一定程度上减缓了氢气处理后银粒子的大量聚集, 从而 提高了催化活性.

\section{2. 银基双金属催化剂}

相对于其它贵金属 $\mathrm{Au}$ 和Pd等, Ag更容易吸附和活 化氧分子, 因此近年来很多人合成出银基双金属催化剂 以提高催化剂对分子氧的活化能力, 加速 CO的催化氧 化.

$\mathrm{Au}$ 等负载型贵金属催化剂虽然表现出较高的催化 $\mathrm{CO}$ 氧化活性, 甚至在 $0^{\circ} \mathrm{C}$ 以下完全转化 ${ }^{[2]}$, 但是存在热 稳定性差和易失活等缺点. 最近很多人用 $\mathrm{Ag}$ 来改变主 活性金属的电子结构, 活化氧分子, 从而提高催化剂活 性和稳定性 ${ }^{[37,38,84 \sim 94]}$. Mou课题组 ${ }^{[37,38,84 ~ 87]}$ 通过制备 $\mathrm{Au}-\mathrm{Ag}$ 合金粒子, 使得Ag活化的氧分子很容易与 $\mathrm{Au}$ 活化 的 $\mathrm{CO}$ 分子反应生成 $\mathrm{CO}_{2}$. Wang 等 ${ }^{[88}$ 通过产物瞬时分析 反应器(TAP)发现, Ag活化的氧可以在常温下被Au粒子 所储存. Chou等 ${ }^{[90]}$ 通过原位定时扫描隧道电子显微镜 和密度泛函理论(DFT)计算证实, Au的存在使得 $\mathrm{Ag}(110)$ 上的氧在 $\mathrm{CO}$ 氧化过程中被迅速消耗. $\mathrm{Au}-\mathrm{Ag}$ 合金粒子 催化氧化CO过程的动力学研究显示, 当 $\mathrm{Au}$ 表面含有少 量 $\mathrm{Ag}$ 时, 在 $\mathrm{Au}-\mathrm{Ag}$ 界面处共吸附 $\mathrm{CO}$ 和 $\mathrm{O}_{2}$ 形成的 $\left(\mathrm{CO}_{3}\right)^{*}$ 被 $\mathrm{CO}$ 和 $\mathrm{O}_{2}$ 之间的作用力成功分解为 $\mathrm{CO}_{2}{ }^{[91]}$. 此外, 通过 改变处理条件调变Pd-Ag粒子结构, 结果表明, 合金粒子 以Pd粒子挨着分散的Ag粒子方式重排表现出最高的催 
化活性 ${ }^{[92]}$.

\section{6. 反应过程中其它气氛的影响}

不同的应用领域对其所需 $\mathrm{CO}$ 低温氧化催化剂的要 求也不尽相同. 研究不同环境气氛对低温催化 $\mathrm{CO}$ 氧化 性能的影响, 不仅可以深入了解催化反应机理, 而且对 于相关催化体系的开发及应用具有重要意义. $\mathrm{CO}$ 中 $\mathrm{H}_{2}$, $\mathrm{H}_{2} \mathrm{O}$ 和 $\mathrm{CO}_{2}$ 的存在必然会对催化剂低温活性和稳定性产 生一定的影响.

\section{1. $H_{2}$ 的影响}

由于燃料电池的电极对燃料氢气中存在少量的 $\mathrm{CO}$ 具有极高的敏感性, 因此寻找在富氢气氛下选择性氧化 脱除CO的催化剂成为研究热点之一. 目前, 相关银催化 剂的研究很多, 但是最大的问题就是选择性低. 我 们 ${ }^{[30,95 ~ 99]}$ 通过调节处理条件等因素制备了不同结构的 $\mathrm{Ag} / \mathrm{SiO}_{2}$ 催化剂, $\mathrm{CO}$ 的最大转化率不超过 $60 \%, \mathrm{CO}_{2}$ 选择 性低于 $40 \%$. Derekayal等 ${ }^{[49]}$ 研究发现, $\mathrm{Ag} / \mathrm{Co} / \mathrm{Ce}$ 催化剂 能在 $150{ }^{\circ} \mathrm{C}$ 左右实现 CO 完全转化, 但选择性极低 $(<$ $20 \%)$, 且其低温 $\left(<80^{\circ} \mathrm{C}\right)$ 下基本没有活性. Chen等 ${ }^{[100,101]}$ 把 $\mathrm{Ag}$ 负载在活性炭上, 在 $100{ }^{\circ} \mathrm{C}$ 左右能够实现CO完全 转化, 但选择性仍不到 $20 \%$. 研究表明, Ag-Co和Ag-Mn 催化剂在CO选择氧化中表现出较高的选择性, 但是其 完全转化温度较高 ${ }^{[102,103]}$. Hu等 ${ }^{[103]}$ 发现, Ag/OMS-2 催 化剂在富氢气氛下于 $120^{\circ} \mathrm{C}$ 可实现CO的完全转化, 而且 具有较高的选择性(90\%)和稳定性(250 h).

\section{2. 水的影响}

各种环境中都不可避免地存在水, 但有关水对银催 化剂催化CO低温氧化性能影响的报道并不多. 研究表 明 ${ }^{[55,104,105]}$, 微量水的存在提高了催化剂性能. Afanasev 等 ${ }^{[55]}$ 和 $\mathrm{Wu}$ 等 ${ }^{[104]}$ 研究显示, 微量水能阻止银表面碳酸盐 的形成, 从而增加其活性. Su等 ${ }^{[105]}$ 通过DFT计算发现, 吸附的水不仅影响 $\mathrm{CO}$ 和 $\mathrm{O}_{2}$ 的吸附, 还影响反应过程的 过渡态和中间产物. 吸附的水能够在 $A g(111)$ 面上形成 氢键, 促进 $\mathrm{O}_{2}$ 的解离, 形成的原子 $\mathrm{O}$ 进一步与水形成羟 基, 可促进 $\mathrm{CO}$ 氧化. 然而, 目前仍缺乏水含量对 $\mathrm{CO}$ 低温 氧化催化剂性能影响的系统研究, 有待于进一步进行.

\section{7. $\mathrm{CO}$ 和 $\mathrm{O}_{2}$ 的吸附过程及反应机理}

\section{1. $\mathrm{CO}$ 和 $\mathrm{O}_{2}$ 的吸附过程}

$\mathrm{CO}$ 和 $\mathrm{O}_{2}$ 在 $\mathrm{Ag}$ 表面的吸附过程涉及到物理化学、表 面科学等众多研究领域, 对其进行深入研究. 有助于理 解 $\mathrm{CO}$ 和 $\mathrm{O}_{2}$ 的活化过程及与 $\mathrm{Ag}$ 的作用, 以及表面反应和
催化过程的本质. 目前这方面的研究主要集中在理论计 算及模型催化剂上 ${ }^{[106 ~ 127] . ~}$

DFT和质谱和动力学研究发现 ${ }^{[107 ~ 112]}, \mathrm{CO}$ 在银簇上 的最优吸附位是顶位吸附, 易与吸附氧之后的银簇发生 反应. 此外, 采用DFT B3LYP方法研究 $\mathrm{Ag}_{2}{ }_{2}^{-}$催化CO氧化 反应机理发现, $\mathrm{CO}$ 能在室温下被完全转化 ${ }^{[113]}$; 并且 $\mathrm{O}_{2}$ 分子很容易在 $\mathrm{Ag}_{2}{ }^{-}$上发生部分解离, 这种游离的化学吸 附影响了 $\mathrm{O}_{2}$ 分子在 $\mathrm{Ag}_{2}{ }^{-}$上的吸附 ${ }^{[114]}$. 在 $\mathrm{Ag}_{2}{ }^{-}$银簇上, $\mathrm{CO}$ 催化氧化反应共有四条可能的反应途径：其中最可 能的是 $\mathrm{CO}$ 插入 $\mathrm{Ag}_{2} \mathrm{O}_{2}^{-}$中的 $\mathrm{Ag}-\mathrm{O}$ 键形成中间体 $[\mathrm{Ag}-\mathrm{AgC}(\mathrm{O}-\mathrm{O}) \mathrm{O}]^{-}$, 然后直接分解形成产物 $\mathrm{CO}_{2}$ 和 $\mathrm{Ag}_{2} \mathrm{O}^{-}$, 或另一分子 $\mathrm{CO}$ 进攻中间体 $[\mathrm{Ag}-\mathrm{AgC}(\mathrm{O}-\mathrm{O}) \mathrm{O}]^{-}$形 成两分子产物 $\mathrm{CO}_{2}$ 和 $\mathrm{Ag}_{2}{ }^{-[115]}$.

此外, 人们还采用 $X$ 射线光电子能谱(XPS), 扫描隧 道电子显微镜(STM) 和理论计算等方法研究了 $\mathrm{CO}$ 和 $\mathrm{O}_{2}$ 在 $\mathrm{Ag}$ 不同晶面上的吸附行为. $\mathrm{CO}$ 和 $\mathrm{O}$ 在 $\mathrm{Ag}(001)$ 表面共 吸附的XPS谱显示, CO倾向于与表面上可扩散的O原子 相互作用, 并且通过这种方式将氧固定在表面 ${ }^{[116]}$. 此过 程的反应途径是 $\mathrm{CO}+\mathrm{O}_{2} \rightarrow \mathrm{O}_{2} \cdots \mathrm{CO} \rightarrow \mathrm{CO}_{2}+\mathrm{O}^{[117]}$. 在 $\mathrm{Ag}(110)$ 表面上, 低于 $\mathrm{O}_{2}$ 的分解温度时, $\mathrm{CO}$ 以分子束形 式进入 $\mathrm{O}_{2}$ 阶层 ${ }^{[118,119]}$; 而CO只能在高压和低温条件下在 $\operatorname{Ag}(111)$ 表面发生很弱的化学吸附 ${ }^{[120]}$. 与 Schmeisse 等 ${ }^{[121]}$ 和 Jänsch等 ${ }^{[122]}$ 的实验一致. 而Hammer等 ${ }^{[123]}$ 和江 凌等 ${ }^{[124]}$ 研究发现, CO分子在 $\mathrm{Ag}$ 单晶表面上发生的是解 离性吸附。

\section{2. $\mathrm{CO}$ 氧化机理}

研究发现, 载体不同, 其负载的银催化剂上CO氧化 反应不同. 在 $\mathrm{Ag} / \mathrm{SiO}_{2}$ 催化剂上, 不同的反应温度区间存 在着不同的速控步骤 ${ }^{[54]}$. 在低温区, 氧解离是速控步骤, 能相对容易地发生在小尺寸银粒子上; 高温区氧更容易 活化而不依赖于银粒子尺寸, CO在银表面的可逆吸附 成为速控步骤. 而在 $\mathrm{Ag} / \mathrm{NaY}$ 催化剂上, $\mathrm{Ag}^{+}$的还原是增 强 $\mathrm{CO}$ 氧化活性的必要步骤, $\mathrm{CO}$ 氧化过程遵循一级反应 动力学 ${ }^{[128]}$.

活性载体负载的纳米银催化剂上CO氧化反应机理 比较复杂. 通常认为, 在 $\mathrm{Ag}$ 和 $\mathrm{M}(\mathrm{Mn}, \mathrm{Co}, \mathrm{Ce})$ 催化剂体 系中, $\mathrm{CO}$ 能在 $\mathrm{Ag}^{+}-\mathrm{O}$ 位上快速氧化, 而 $\mathrm{M}$ 上的 $\mathrm{O}$ 会重新氧 化 $\mathrm{Ag}^{0}$ (见图8), 银的再氧化所需的 $\mathrm{O}$ 来自于 $\mathrm{M}$ (Mn, Co和 $\mathrm{Ce})$ 氧化物的氧脱附 ${ }^{[60,66,81]}$. 在 $\mathrm{Ag} /$ 过渡金属氧化物催化 剂上, $\mathrm{CO}$ 的氧化遵循着氧化还原反应机理 ${ }^{[72]}$. 在温度较 低时, 催化剂表面CO的氧化是整个反应的速控步骤; 当 温度升至 $473 \mathrm{~K}$ 后, $\mathrm{CO}$ 的吸附开始成为影响反应过程的 
控制因素.

\section{8. 结论与展望}

综上所述, 负载型银催化剂低温催化CO具有广泛 的应用前景. 其性能主要受制备方法, 预处理条件, 载体 和粒子尺寸等因素影响. 目前有效的常温 $\mathrm{CO}$ 催化氧化 催化剂的制备方法主要为直接合成法和浸渍法等, 载体 通常为介孔硅基材料, 所制催化剂的高活性离不开有效 的预处理(包括气氛和温度). 在制备 $\mathrm{CO}$ 氧化的银催化剂 过程中, 各种影响因素是相互影响、相互制约的.

有关 $\mathrm{Ag}$ 基催化剂上 $\mathrm{CO}$ 氧化反应的研究, 人们已经 形成了三点共识：(1)在惰性载体上, 银粒子在反应过程 中表现出明显的粒子尺寸效应; (2)载体不同, 银催化剂 的活化气氛有所不同, 对于惰性载体, 如二氧化硅, 焙烧
之后的低温氢气处理更有利于银的分散和反应活性的 提高, 而对于活性载体, 如 $\mathrm{CeO}_{2}$ 和 $\mathrm{MnO}_{2}$, 焙烧更有利于 催化活性的提高; (3)不同载体催化剂上的反应机理也 有所不同, 对于惰性载体, $\mathrm{CO}$ 和 $\mathrm{O}_{2}$ 分子的吸附和解离过 程发生在银表面或界面上, 因此其反应活性与银粒子的 尺寸有很大关系; 而对于活性载体, 载体的晶格氧及银氧-过渡金属之间的电子传递对于催化活性起着至关重 要的作用. 然而, 在真实气氛下的相关研究还不多, 如考 察水及 $\mathrm{CO}_{2}$ 对银催化剂结构及活性的影响等; 银催化剂 上CO氧化反应机理也还不明确, $\mathrm{CO}$ 和 $\mathrm{O}_{2}$ 分子是如何在 催化剂表面迁移和转化的, 还需要进一步采用原位等谱 学手段进行研究与探讨. 深入系统地研究银催化剂上真 实气氛中的 $\mathrm{CO}$ 氧化过程, 必将使其在实际工业和环境 (包括隧道以及室内净化)中得到更广泛的应用. 